\title{
Fractalkine Signaling Regulates Macrophage Recruitment into the Cochlea and Promotes the Survival of Spiral Ganglion Neurons after Selective Hair Cell Lesion
}

\author{
Tejbeer Kaur, ${ }^{1}$ Darius Zamani, ${ }^{1,3}$ Ling Tong, ${ }^{4}$ Edwin W. Rubel, ${ }^{2,4}$ Kevin K. Ohlemiller, ${ }^{1}$ Keiko Hirose, ${ }^{1}$ \\ and Mark E. Warchol ${ }^{1}$ \\ ${ }^{1}$ Department of Otolaryngology, Washington University School of Medicine, St. Louis, Missouri 63110, ${ }^{2}$ Department of Otolaryngology, University of \\ Washington School of Medicine, Seattle, Washington 98105, ${ }^{3}$ Department of Communication Sciences and Disorders, University of South Florida, Tampa, \\ Florida 33620, and ${ }^{4}$ Virginia Merrill Bloedel Hearing Research Center, University of Washington, Seattle, Washington 98105
}

Macrophages are recruited into the cochlea in response to injury caused by acoustic trauma or ototoxicity, but the nature of the interaction between macrophages and the sensory structures of the inner ear remains unclear. The present study examined the role of fractalkine signaling in regulating the injury-evoked behavior of macrophages following the selective ablation of cochlear hair cells. We used a novel transgenic mouse model in which the human diphtheria toxin receptor (huDTR) is selectively expressed under the control of Pou4f3, a hair cell-specific transcription factor. Administration of diphtheria toxin (DT) to these mice resulted in nearly complete ablation of cochlear hair cells, with no evident pathology among supporting cells, spiral ganglion neurons, or cells of the cochlear lateral wall. Hair cell death led to an increase in macrophages associated with the sensory epithelium of the cochlea. Their numbers peaked at 14 days after DT and then declined at later survival times. Increased macrophages were also observed within the spiral ganglion, but their numbers remained elevated for (at least) $56 \mathrm{~d}$ after DT. To investigate the role of fractalkine signaling in macrophage recruitment, we crossed huDTR mice to a mouse line that lacks expression of the fractalkine receptor $\left(\mathrm{CX}_{3} \mathrm{CR} 1\right)$. Disruption of fractalkine signaling reduced macrophage recruitment into both the sensory epithelium and spiral ganglion and also resulted in diminished survival of spiral ganglion neurons after hair cell death. Our results suggest a fractalkine-mediated interaction between macrophages and the neurons of the cochlea.

Key words: cochlea; fractalkine; hair cells; macrophages; neuroprotection; spiral ganglion neurons

Significance Statement

It is known that damage to the inner ear leads to recruitment of inflammatory cells (macrophages), but the chemical signals that initiate this recruitment and the functions of macrophages in the damaged ear are unclear. Here we show that fractalkine signaling regulates macrophage recruitment into the cochlea and also promotes the survival of cochlear afferents after selective hair cell lesion. Because these afferent neurons carry sound information from the cochlea to the auditory brainstem, their survival is a key determinant of the success of cochlear prosthetics. Our data suggest that fractalkine signaling in the cochlea is neuroprotective, and reveal a previously uncharacterized interaction between cells of the cochlea and the innate immune system.

\section{Introduction}

Resident macrophages are present in most somatic tissues, where they play critical roles in innate immunity, homeostasis, and injury response (Stefater et al., 2011). The mammalian cochlea contains a population of resident macrophages, and increased

Received June 17, 2015; revised Sept. 3, 2015; accepted Sept. 12, 2015.

Author contributions: T.K., D.Z., E.W.R., K.H., and M.E.W. designed research; T.K., D.Z., L.T., and K.K.O. performed research; T.K., D.Z., K.K.O., and M.E.W. analyzed data; T.K., E.W.R., K.K.O., and M.E.W. wrote the paper.

This work was supported by the National Institutes of Health Grants R01DC006283 to M.E.W., R01DC003829 to E.W.R., and P30DC004665 and P30DC004661. D.Z. was supported by National Institutes of Health T35 Grant DC008765.

The authors declare no competing financial interests. numbers of macrophages are recruited into the cochlea after acoustic trauma or ototoxic injury (Fredelius and RaskAndersen, 1990; Hirose et al., 2005; Sato et al., 2010). Still, the precise role of macrophages in the lesioned cochlea is not known and the signals that recruit macrophages into injured ear have not

Correspondence should be addressed to Dr. Mark E. Warchol, Department of Otolaryngology, Washington University School of Medicine, 660 South Euclid Avenue, Box 8115, St. Louis, MO 63110. E-mail: Warcholm@ent.wustl.edu.

D. Zamani's present address: Department of Communication Sciences and Disorders, University of Florida, Tampa, FL 33620.

D0I:10.1523/JNEUROSCI.2325-15.2015

Copyright $\odot 2015$ the authors $\quad 0270-6474 / 15 / 3515050-12 \$ 15.00 / 0$ 
been identified. Prior studies of injury-evoked macrophage recruitment in the cochlea have used either noise or ototoxic antibiotics to kill sensory hair cells. However, both of these methods can damage other cochlear tissues, and it is not clear whether the loss of hair cells alone can result in macrophage activation and recruitment. To determine whether the loss of cochlear hair cells (without any other direct tissue injury) was sufficient to recruit macrophages into the cochlea, we used a novel transgenic mouse model, in which the gene for the human diphtheria toxin receptor $(h u D T R)$ was inserted under regulation of the promoter for Pou4f3 (a hair cell-specific transcription factor). In these mice, a single injection of diphtheria toxin (DT) kills nearly all cochlear hair cells but does not affect the nonsensory tissues of the inner ear (Tong et al., 2015). The Pou4f3-huDTR mice were crossed with a second transgenic line, in which one or both alleles of the fractalkine receptor $C X_{3} C R 1$ was replaced with the gene for GFP. $\mathrm{CX}_{3} \mathrm{CR} 1$ is expressed by macrophages, monocytes, microglia, and related cells. As such, the $\mathrm{CX}_{3} \mathrm{CR} 1-\mathrm{GFP}$ mouse line expresses GFP in all macrophages, permitting us to characterize the numbers and location of macrophages within the injured cochlea.

Use of the $\mathrm{CX}_{3} \mathrm{CR} 1-\mathrm{GFP}$ mouse line also permitted us to investigate the role of fractalkine signaling in cochlear pathology. Fractalkine (also known as $\mathrm{CX}_{3} \mathrm{CL} 1$ ) is a transmembrane glycoprotein that is widely expressed on neurons (Harrison et al., 1998), endothelial cells (Bazan et al., 1997), and epithelial cells (Lucas et al., 2001), and is involved in two distinct processes: Soluble fractalkine can act as macrophage chemoattractant, whereas membrane-bound fractalkine can serve as an adhesion molecule between macrophages and adjoining cells. In the CNS, fractalkine signaling mediates interactions between neurons and microglia (Cardona et al., 2006; Bhaskar et al., 2010; Paolicelli et al., 2011). However, the possible role of fractalkine in neuralimmune interactions outside of the CNS has not been explored. To examine the role of fractalkine signaling after hair cell injury, we used mice in which both alleles of $\mathrm{CX}_{3} \mathrm{CR} 1$ had been replaced with GFP.

We found that DT-evoked hair cell death led to increased macrophage numbers within the cochlea and spiral ganglion. The numbers of cochlear macrophages peaked at $14 \mathrm{~d}$ after DT injection, whereas macrophage numbers within the spiral ganglia remained elevated as late as $56 \mathrm{~d}$ after DT. In addition, we found that interruption of fractalkine signaling after hair cell death resulted in decreased macrophages associated with both the sensory epithelium and the spiral ganglion. Furthermore, deletion of $\mathrm{CX}_{3} \mathrm{CR} 1$ led to reduced survival of spiral ganglion neurons (SGNs) after hair cell injury. Our findings point to an unexpected interaction between cells of the innate immune system and the afferent neurons of the cochlea, and imply that fractalkine signaling may protect SGNs after hair cell loss.

\section{Materials and Methods}

Animals. All studies used transgenic mice generated on a C57BL/6J background. One mouse line expressed the gene for the human DT receptor ( $h u D T R$; heparin-binding epidermal growth factor receptor) under regulation of the Pou 43 promoter. Generation and characterization of these mice have been previously described (Tong et al., 2011, 2015; Golub et al., 2012), and systemic treatment with DT results in specific ablation of hair cells in the inner ear. Heterozygous Pou4f3-huDTR mice were crossed to $C X_{3} C R 1^{G F P / G F P}$ mice (Dan Littmann, New York University, New York). These mice express GFP in all macrophages, monocytes, and microglia (Jung et al., 2000). In one set of experiments, double heterozygotes $\left(\mathrm{CX}_{3} \mathrm{CR} 1^{+/ \mathrm{GFP}}:\right.$ Pou $\left.4 \mathrm{f3}^{\mathrm{DTR} /+}\right)$ were used as experimental mice and single heterozygotes $\left(\mathrm{CX}_{3} \mathrm{CR} 1^{+/ \mathrm{GFP}}:\right.$ Pou $\left.4 \mathrm{f3}^{+/+}\right)$served as controls. A second series of experiments examined the effects of $\mathrm{CX}_{3} \mathrm{CR} 1$ deletion and used $C X_{3} C R 1^{+/-}:$Pou $43^{\text {DTR/+ }}$ and $C X_{3} C R 1^{-1-}:$ Pou $4 f 3^{\text {DTR/+ }}$ as experimen- tal mice and $\mathrm{CX}_{3} C R 1^{+/-}$:Pou $43^{+/+}$and $\mathrm{CX}_{3} C R 1^{-/-}$:Pou $43^{+/+}$as controls. Mice were housed in the animal facility at the Central Institute for the Deaf (Washington University) and were maintained on a 12 h/day-night light cycle with open access to food and water. All experimental protocols involving animals were approved by the Animal Studies Committee of the Washington University School of Medicine (St. Louis, MO).

Genotyping. Identification of Pou $43^{\mathrm{DTR} /+}$ and Pou $43^{+/+}$mice used methods similar to those described by Tong et al. (2015). Briefly, tail biopsies were collected, and DNA was extracted using ethanol precipitation. The targeted allele was amplified using PCR (Quick-Load Taq $2 \times$ Master Mix, New England Biolabs) using the following primers $(0.4 \mu \mathrm{M})$ : Pou4f3 (WT) forward, 5' CAC TTG GAG CGC GGA GAG CTA G; Pou4f3 (mutant) reverse, 5' CCG ACG GCA GCA GCT TCA TGG TC. PCRs were run using the following conditions: $95^{\circ} \mathrm{C}$ for $5 \mathrm{~min} ; 95^{\circ} \mathrm{C}$ for $30 \mathrm{~s}, 59^{\circ} \mathrm{C}$ for $30 \mathrm{~s}, 72^{\circ} \mathrm{C}$ for $1 \mathrm{~min}, 30$ cycles; $72^{\circ} \mathrm{C}$ for $7 \mathrm{~min} ; 4^{\circ} \mathrm{C}$ infinity. PCR products (expected band $\sim 150 \mathrm{bp}$ ) were separated on $2 \%$ agarose gel containing $1 \mu \mathrm{l} / \mathrm{ml}$ SYBR safe DNA gel stain (Invitrogen). Identification of $C X_{3} C R 1^{+/ G F P}$ (GFP heterozygous) and $C X_{3} C R 1^{\text {GFP/GFP }}$ (GFP homozygous) followed previously described methods (Jung et al., 2000).

Hair cell ablation. Both experimental and control mice (6-8 weeks old; either sex) received a single intramuscular injection of DT (25 ng/g, Sigma-Aldrich). Body weights were recorded daily, and mice also received daily intraperitoneal injections of $0.5 \mathrm{ml}$ of lactated Ringer's solution, at days 3-6 after DT or until body weights had stabilized. Mouse food was also supplemented with high-calorie gel (Tomlyn from Nutrical). At 1-56 d after DT injection, mice were deeply anesthetized with Somnasol and perfused with phosphate-buffered 4\% PFA (Electron Microscopy Sciences). Temporal bones were removed and postfixed for $1 \mathrm{~h}$ in $4 \%$ PFA, rinsed in PBS, and placed in $0.1 \mathrm{~m}$ EDTA, to allow decalcification for whole-mount dissections and sectioning.

BrdU administration. To determine whether resident cochlear macrophages undergo proliferation in response to hair cell lesions, both $\mathrm{CX}_{3} C R 1^{+/ \mathrm{GFP}}:$ Pou $43^{\mathrm{DTR} /+}$ and $\mathrm{CX}_{3} \mathrm{CR} 1^{+/ \mathrm{GFP}}:$ Pou $43^{+/+}$adult mice (6-8 weeks) received a single intramuscular injection of DT $(25 \mathrm{ng} / \mathrm{g}$, Sigma-Aldrich) and were allowed to survive for a total of 24 or $48 \mathrm{~h}$. At $4 \mathrm{~h}$ before death and perfusion, the mice then received a single intraperitoneal injection of BrdU (100 mg/kg body weight, catalog \#B5002, Sigma Aldrich). Fixed cochleae were processed for BrdU immunohistochemistry.

Auditory brainstem response (ABR). Before and 1 week after DT injection, ABRs to tone pips were quantified for both experimental and control subjects. Mice were first anesthetized via intraperitoneal injections of ketamine $(100 \mathrm{mg} / \mathrm{kg})$ and xylazine $(20 \mathrm{mg} / \mathrm{kg})$. Subcutaneous electrodes were placed behind the right pinna (inverting) and vertex (active). A ground electrode was placed near the tail of the mouse. Stimuli were $5 \mathrm{~ms}$ tone pips $\left(0.5 \mathrm{~ms} \cos ^{2}\right.$ rise-fall), delivered at $40 / \mathrm{s}$ with alternating stimulus polarity. Recorded electrical responses were amplified $(\sim 10,000 \times)$, filtered ( $100 \mathrm{~Hz}$ to $3 \mathrm{kHz}$ ), and averaged, using BioSig software (TuckerDavis Technologies). The sound level was decreased in $5 \mathrm{~dB}$ steps from 99 $\mathrm{dB}$ SPL down to $15 \mathrm{~dB}$ SPL. At each sound level, 1024 responses were averaged, and response waveforms were discarded as artifacts if the peakto-peak voltage exceeded $15 \mu \mathrm{V}$. Thresholds at 5.6, 8, 11, 16, 22.63, 32, 45.2 , and $64 \mathrm{kHz}$ were determined by a single observer, who noted the lowest sound level at which a recognizable waveform could be obtained. Waveforms were confirmed as auditory-evoked responses by their increasing latency and decreasing amplitude as the intensity of the stimulus was lowered. If a hearing threshold at a particular stimulus frequency could not be detected at a sound level of $<99 \mathrm{~dB}$, a threshold of " $100 \mathrm{~dB}$ " was assigned for that frequency. These threshold values (actual or assigned) were then used to calculate the mean ABR thresholds at each stimulus frequency.

Distortion product otoacoustic emissions. Mice were anesthetized as described above. Stimuli were presented at $5-40 \mathrm{kHz}$ and delivered to the right ear by a custom-coupling insert. Distortion product otoacoustic emissions (DPOAEs) were elicited for primary tones $\mathrm{f} 1$ and $\mathrm{f} 2$, with a frequency ratio $\mathrm{f} 2 / \mathrm{f} 1$ of 1.2 and $\mathrm{f} 1$ typically presented at a level $10 \mathrm{~dB}$ above f2). Recordings were performed using EMAV software (Boystown National Research Hospital). 
Endocochlear potential recording. Endocochlear potentials were measured at $3 \mathrm{~d}$ after DT injection. Measurements were made from both experimental (Pou $43^{\text {DTR/+ }}$ ) and control $\left(\right.$ Pou $\left.43^{+/+}\right)$mice, using techniques described previously (Ohlemiller et al., 2006). Briefly, a fine drill was used to make a hole in the left cochlear capsule, directly over scala media of the lower basal turn. Glass capillary pipettes filled with $0.15 \mathrm{M} \mathrm{KCl} \mathrm{(40-80}$ MOhms) were mounted on a hydraulic microdrive (Frederick Haer) and advanced until a stable positive potential that did not change with increased electrode depth was noted. The signal from the recording electrode was fed to an AM Systems model 1600 intracellular amplifier.

Histological methods. After perfusion, cochleae were isolated and processed for immunohistochemical labeling. Proteins were detected in both cochlear whole mounts and frozen mid-modiolar sections using standard immunofluorescence methods. Briefly, tissue was rinsed with PBS $(3 \times)$ and incubated at room temperature for $2 \mathrm{~h}$ in blocking solution ( $5 \%$ normal horse serum in $0.2 \%$ Triton X-100 in PBS). Cochleae were incubated overnight at room temperature with combinations of the following primary antibodies: Hair cells were labeled with an antibody against anti-myosin VIIa (catalog \#25-6790, Proteus Biosciences, 1:500). The apical surfaces of the sensory epithelia were stained using Phalloidin (catalog \#A12379, Invitrogen; $25 \mu \mathrm{l} / \mathrm{ml}$ ). Neuronal peripheral processes and ganglion cell bodies were labeled using a combination of antiNeurofilament (mouse monoclonal, clone $\# 2 \mathrm{H} 3$, Developmental Studies Hybridoma Bank, University of Iowa, 1:100) and anti- $\beta$-III tubulin antibodies (mouse monoclonal, catalog \#MMS-435P, Covance, 1:500). Nuclei of supporting cells were labeled using an antibody against SOX2 (catalog \#SC-17320, Santa Cruz Biotechnology, 1:200). Visualization of GFP-expressing macrophages was enhanced using rabbit anti-GFP (catalog \#A11122, Invitrogen, 1:500), and active macrophages were labeled using mouse anti-CD68 (catalog \#MCA 1957, AbD Serotec, 1:50). Two different antibodies against the chemotactic domain of $\mathrm{CX}_{3} \mathrm{CL} 1$ were used to verify the expression pattern of $\mathrm{CX}_{3} \mathrm{CL1}$ : Abcam (catalog \#ab25088, 1:100) and R\&D Systems (catalog \#AF537, $5 \mu \mathrm{g} / \mathrm{ml}$ ). Proliferating cells were labeled using mouse anti-BrdU (catalog \#347580, BD Biosciences, 1:50). Following incubation in primaries, specimens were rinsed $5 \times$ in PBS and treated for $2 \mathrm{~h}$ in secondary antibodies, conjugated to either AlexaFluor-488, -546, -555, or -647 (1:500; Invitrogen). The secondary antibody solutions also contained DAPI (catalog \#D9542, Sigma-Aldrich, $1 \mu \mathrm{g} / \mathrm{ml}$ ), to label cell nuclei. Proliferating (S-phase) cells were identified via BrdU immunohistochemistry (Warchol et al., 2012). Macrophages that were both BrdU- and GFP-labeled were considered to be undergoing proliferation. All specimens were coverslipped in glycerol: PBS (9:1) before microscopic imaging.

For plastic embedding, decalcified cochleae were osmicated $\left(1 \% \mathrm{OsO}_{4}\right.$ in $\mathrm{dH}_{2} \mathrm{O}$ ) for $60 \mathrm{~min}$, dehydrated in serial ethanols and propylene oxide, embedded in Araldite resin, and incubated for $3 \mathrm{~d}$ at $60^{\circ} \mathrm{C}$. The cochleae were serial sectioned with a carbide steel knife into $20 \mu \mathrm{m}$ sections.

Cellular imaging and analyses. Fluorescence imaging was performed using a Zeiss LSM 700 confocal microscope. For all cochleae, $Z$-series images $(10 \times, 20 \times, 40 \times$, or $60 \times)$ were obtained, beginning at apical surface of hair cells and extending through the neuronal innervation. Image processing and quantitative analysis were performed using Volocity 3D image analysis software (version 6.1.1, PerkinElmer).

Cochlear hair cell and supporting cell counts. The time course of hair cell loss was assessed at 1, 3, 7, and $14 \mathrm{~d}$ after DT, in both Pou $43^{+/+}$(WT) and Pou $4 \mathrm{f}^{D T R /+}$ mice ( $n=5$ or 6 per group). Mice were terminally anesthetized with Somnasol $(50 \mathrm{mg} / \mathrm{kg}$ ) and transcardially perfused with $4 \%$ PFA. Temporal bones were isolated, the stapes was removed from the oval window, and tissue was removed from the round window. The temporal bones were kept in 4\% PFA for an additional $1 \mathrm{~h}$ at room temperature. After fixation, the tissue was rinsed three times with PBS and then immersed in $0.1 \mathrm{M}$ EDTA to allow decalcification for cochlear whole-mount dissections. The cochlea was microdissected into apical, middle, and basal region. The stria vascularis was trimmed, and the tectorial membrane was removed with \#55 forceps. Whole-mount preparations were then processed for immunolabeling, as described above. Hair cells were identified by their immunoreactivity for myosin VIIA, whereas supporting cells were identified by nuclear immunoreactivity for SOX2. Both cell types were counted from the apical, middle, and basal region of the cochlea, as recorded in $40 \times$ objective images. Data were expressed as either hair cell survival (\% control) or SOX2-positive cells/10,000 $\mu \mathrm{m}^{2}$.

Macrophage counts. The time course of macrophage numbers was assessed at 1, 3, 7, 14, 28, and $56 \mathrm{~d}$ after DT injection in both adult Pou $4 \mathrm{f}^{+/+}$(WT) and Pou $4 \mathrm{f}^{\mathrm{DTR} /+}$ mice ( $n=6$ or 7 per group). To assess macrophages per $100 \mu \mathrm{m}$ of sensory epithelium, GFP-labeled macrophages were counted from $20 \times$ images taken from the middle region of cochlear whole mounts. To assess macrophages in the spiral ganglia, GFP-labeled macrophages were counted from $20 \times$ images taken from the lower basal (base), upper basal (middle), and apical portions of the Rosenthal's canal of sectioned specimens. Macrophages in spiral ganglia were counted from at least 4 or 5 sections per cochlea and normalized to the cross-sectional area of the Rosenthal's canal of the respective cochlear turn and averaged and reported as number per $1000 \mu \mathrm{m}^{2}$.

SGN counts. Two different methods were used to assess SGN survival. The first method used immunofluorescence labeling of SGNs. One temporal bone (right) from each animal was used for whole-mount microdissection, whereas the second (left) temporal bone was decalcified in 0.1 м EDTA and frozen-sectioned along the mid-modiolar plane. Serial floating sections $(30 \mu \mathrm{m})$ were immunolabeled using standard immunofluorescence methods. Briefly, tissue was rinsed with PBS $(3 \times)$ and incubated at room temperature for $2 \mathrm{~h}$ in blocking solution ( $5 \%$ normal horse serum in $0.2 \%$ Triton X-100 in PBS). Sections were then incubated overnight at room temperature, and neurons were labeled with a combination of anti-Neurofilament and anti- $\beta$-III tubulin (as described above). Specimens were then rinsed $5 \times$ in PBS and incubated for $2 \mathrm{~h}$ in secondary antibody (AlexaFluor-546 anti-mouse IgG; Invitrogen; 1:500). Specimens were coverslipped in glycerol:PBS (9:1), and fluorescent imaging was performed using a Zeiss LSM 700 confocal microscope. $Z$-series images at $0.3 \mu \mathrm{m}$ intervals were obtained using a $20 \times$ objective. Image processing and quantitative analysis were performed using Volocity $3 \mathrm{D}$ image analysis software (version 6.1.1, PerkinElmer). To assess the numbers of spiral ganglion cell bodies, Neurofilament and $\beta$-III tubulinlabeled somata within Rosenthal's canal were counted from the maximum intensity projections of each section. Cell bodies counted from 4 or 5 sections per cochlea were normalized to the cross-sectional area of Rosenthal's canal per cochlear turn and averaged and reported as SGN density (cells per $1000 \mu \mathrm{m}^{2}$ ).

The second method for assessing SGN survival was by counting spiral ganglion cell bodies in osmicated plastic-embedded sections. Images were obtained from 4 or 5 mid-modiolar sections (20 $\mu \mathrm{m}$ each) per specimen, using an Axiovert 135 inverted microscope (Zeiss) that was equipped with Retiga 1300 camera (Q imaging) and a $63 \times$ NA oilimmersion objective. All images were captured using IP lab software (Scanalytics, version 3.9) the apical, middle, and basal turns of Rosenthal's canal. The images were then exported as TIFF files onto ImageJ 1.42a (National Institutes of Health), and spiral ganglion cell bodies were counted from $100 \mu \mathrm{m} \times 100 \mu \mathrm{m}$ area per turn of the cochlea. From these counts, neuronal profile density (somata per 10,000 $\mu \mathrm{m}^{2}$ area of Rosenthal's canal) was calculated for apical, middle, and basal turns.

Statistical analysis. All the data analysis and statistics were performed using GraphPad Prism version 6.0d. Data are presented as mean \pm SD. Student's $t$ tests or ANOVA was applied as appropriate. Significance main effects or interactions were followed using Bonferroni's or Tukey's post hoc tests. Results were considered statistically significant when $p<0.05$.

\section{Results}

\section{Single DT injection results in complete hair cell death and profound hearing loss}

Previous studies have characterized the Pou $43^{\mathrm{DTR} /+}$ transgenic mouse model and have shown that injection of DT leads to the selective death of inner ear hair cells (Tong et al., 2011, 2015; Golub et al., 2012). Because those previous studies used the Pou4f3-huDTR transgene on a CBA/CaJ background, our initial experiments first characterized cochlear pathology when that same transgene was expressed on C57BL/6J background. Both 

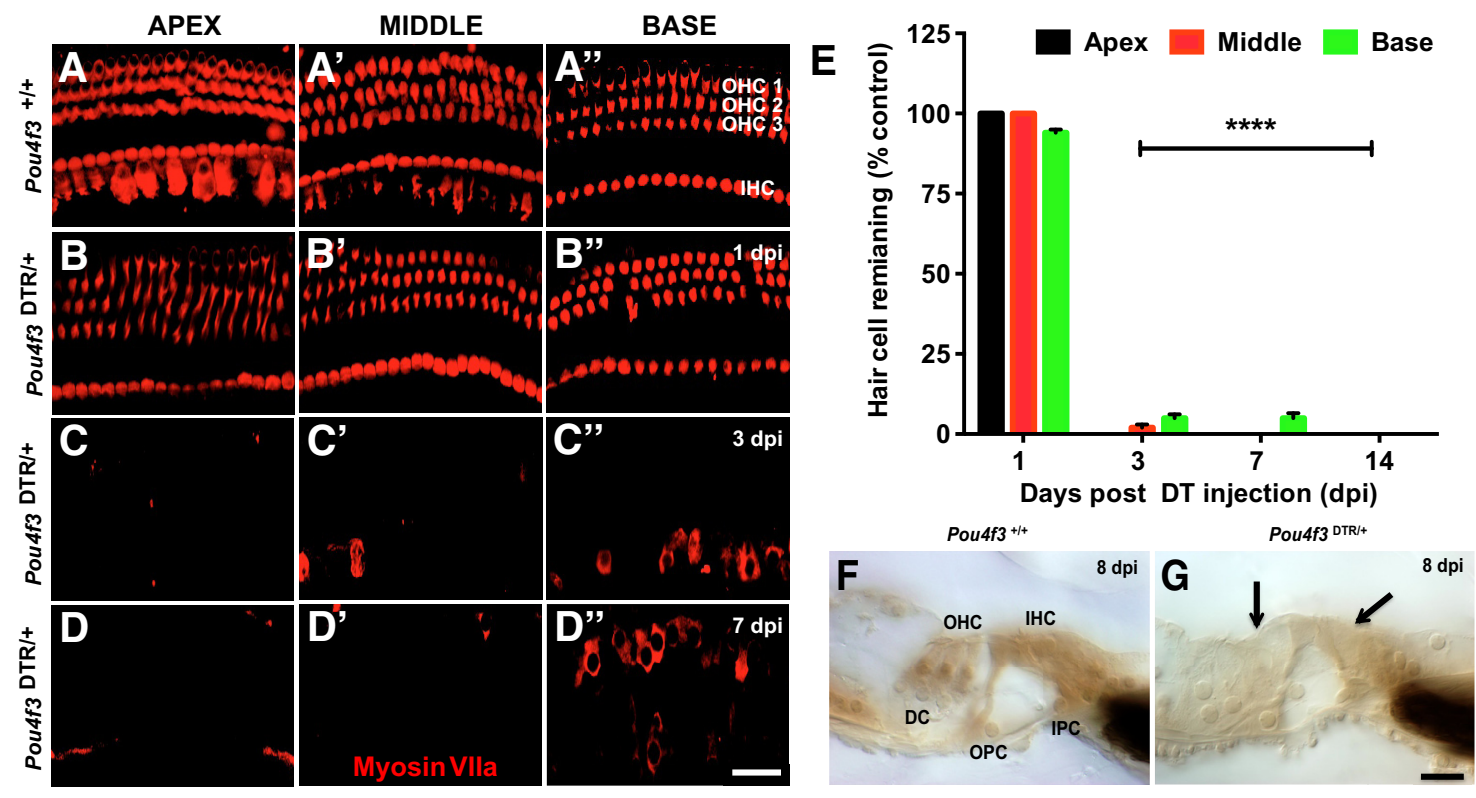

Figure 1. Pou4f ${ }^{\mathrm{DTR} /+}$ mice show extensive loss of hair cells after a single DT injection. $\boldsymbol{A}^{-\boldsymbol{A}^{\prime \prime}}$, Cochlear whole mounts labeled for Myosin VIla (red, hair cells) from Pou4f3 ${ }^{+/+}$mice at $7 \mathrm{~d}$ following DT injection. Hair cells are intact in all the regions of the cochlea, suggesting that DT treatment does not affect the inner ear. $\boldsymbol{B}-\boldsymbol{B}^{\prime \prime}$, Myosin VIlla immunolabeling (red) of cochleae of Pou $4 f 3^{\mathrm{DTR} /+}$ revealed no clear hair cell pathology at $1 \mathrm{~d}$ after DT. $C-C^{\prime \prime}$, Severe loss of hair cells was first evident in the cochleae of Pou $4 f 3^{\text {DTR/+ }}$ mice at $3 \mathrm{~d}$ after DT injection. $D-D^{\prime \prime}$, Loss of cochlear hair cells in Pou $4 f 3^{\mathrm{DTR} /+}$ mice was nearly complete at $7 \mathrm{~d}$ after DT injection. Note the complete ablation of hair cells in the apical and middle region of the cochlea of Pou $4 f 3^{\mathrm{DTR} /+}$ mice, with some remnants of dead hair cells in the basal region. E, Quantification of the percentage of surviving hair cells in Pou4f3 ${ }^{\text {TTR/+ }}$ mice at 1, 3, 7, and $14 \mathrm{~d}$ after DT injections (dpi). Complete loss of hair cells was observed at $14 \mathrm{~d}$ after DT. Data are mean $\pm S D ; n=5$ or 6 cochleae per time point. ${ }^{* * *} p<0.0001,1 \mathrm{dpi} \mathrm{versus} \mathrm{all} \mathrm{other} \mathrm{time} \mathrm{points} \mathrm{at} \mathrm{respective} \mathrm{turn} \mathrm{of} \mathrm{the} \mathrm{cochlea} \mathrm{(two-way} \mathrm{ANOVA} \mathrm{followed}$ by Tukey's multiple comparison post hoc tests). $\boldsymbol{F}$, Plastic-embedded section from DT-treated Pou4f3 ${ }^{+/+}$mouse cochlea (lower apical turn) displaying well-defined nuclei of inner and outer hair cells, and as nuclei of Dieter cells and inner and outer pillar cells. G, Plastic-embedded section from DT-treated Pou4f3 ${ }^{\text {DTR/+}}$ mouse cochlea (lower apical turn) showing the loss of both outer and inner hair cells (arrows). OHC, Outer hair cell; IHC, inner hair cell; D1-3, Deiter's cells; OPC, outer pillar cell; IPC, inner pillar cell. Scale bars: $\boldsymbol{A}-A^{\prime \prime \prime}, \mathbf{B}-\boldsymbol{B}^{\prime \prime \prime}, \mathbf{C}-\boldsymbol{C}^{\prime \prime}, \mathbf{D}-\boldsymbol{D}^{\prime \prime \prime}, 30 \mu \mathrm{m} ; \boldsymbol{F}-\mathbf{G}, 55 \mu \mathrm{m}$.

Pou $43^{+/+}$and Pou $4 \mathrm{f3}^{\mathrm{DTR} /+}$ mice (6 weeks old) were injected with DT (25 ng/g), and temporal bones were isolated at different postinjection time points. DT treatment had no apparent effect on of Pou $43^{+/+}$; healthy-appearing hair cells remained present throughout the cochlea (Fig. $1 A, A^{\prime}, A^{\prime \prime}$ ). In contrast, DT treatment of Pou $43^{\mathrm{DTR} /+}$ mice resulted in the rapid death of both inner and outer hair cells. Intact hair cells were observed at 1 and $2 \mathrm{~d}$ after DT (Fig. $1 B, B^{\prime}, B^{\prime \prime}$; and data not shown for $2 \mathrm{dpi}$ ). However, by $3 \mathrm{~d}$ after DT, almost all hair cells had been ablated, with the exception of a few inner hair cells in the middle and basal turn of the cochlea (Fig. $1 C, C^{\prime}, C^{\prime \prime}$ ). By $7 \mathrm{~d}$ after DT, virtually all hair cells had been lost, although remnants of dead hair cells were observed in the basal turn of the organ of Corti (Fig. $1 D, D^{\prime}, D^{\prime \prime}$ ). Quantification of hair cell numbers at various survival times (Fig. $1 E$ ) confirmed significant hair cell loss at 3 and $7 \mathrm{~d}$ after DT compared with earlier time points or with the cochleae of Pou $43^{+/+}$mice that had also been injected with DT $(p<$ $0.0001)$. Examination of plastic sections revealed that organ of Corti in Pou $43^{+/+}$mice retained a normal appearance at $8 \mathrm{~d}$ after DT (Fig. $1 F$ ), but that the cochleae of Pou $4 \mathrm{f3}^{\mathrm{DTR} /+}$ mice had lost both inner and outer hair cells (Fig. $1 G$, arrows).

A single DT injection in Pou $43^{\text {DTR/+ }}$ mice resulted in profound hearing loss, as assessed by both ABRs and DPOAEs. ABR thresholds of DT-treated mice typically exceeded $90 \mathrm{~dB}$ SPL at all test frequencies (data not shown). In many animals, we were unable to obtain clear ABR responses, even at the highest sound intensities that could be generated by our test apparatus. Similarly, a single DT treatment reduced the amplitude of DPOAEs so that they were indistinguishable from the "noise floor" of the measurement system (data not shown). Prior studies have shown that this functional deficit persists for at least 3 months (Mahrt et al., 2013; Tong et al., 2015). Finally, we measured the endocochlear potential (EP) from the basal cochlear turn in both Pou $43^{+/+}$and Pou $43^{\text {DTR/+ }}$ mice at $3 \mathrm{~d}$ after DT injection. Control $\left(\right.$ Pou $\left.4 \mathrm{f}^{+/+}\right)$mice had an average EP of $101.7 \pm 0.6 \mathrm{mV}(n=$ 3 ), which is normal for mature C57BL/6 mice (Ohlemiller et al., 2009). In contrast, Pou $43^{\mathrm{DTR} /+}$ mice had an average EP of $78.3 \pm$ $7.4 \mathrm{mV}(n=4)$ at $3 \mathrm{~d}$ after DT treatment. Notably, the EP recovered to $102.33 \pm 1.2 \mathrm{mV}(n=3)$ after 1 month recovery from hair cell death. We used light microscopy to examine the stria vascularis in the same Pou $43^{\mathrm{DTR} /+}$ mice following EP measurements and observed no obvious structural changes (data not shown). These data on C57BL/6J mice confirm and extend the data presented earlier by Tong et al. (2015).

\section{DT administration has no direct effect on other cell types in the cochlea}

Although the expression of Pou4f 3 in the ear is restricted to hair cells, we sought to further verify that DT administration did not damage other cells types in the cochlea. Representative photomicrographs from the cochleae of both Pou $4 \mathrm{f3}^{\mathrm{DTR} /+}$ and Pou $4 \mathrm{f3}^{+/+}$ mice, taken at $7 \mathrm{~d}$ (Fig. 2B), $14 \mathrm{~d}$ (Fig. 2C), and $56 \mathrm{~d}$ (Fig. 2D) after DT, showed complete loss of hair cells in Pou $43^{\mathrm{DTR} /+}$ mice, but no signs of supporting cell loss (as identified by SOX2 immunolabeling). The average number of supporting cells $/ 10,000 \mu \mathrm{m}^{2}$ in Pou $43^{+/+}$and Pou $43^{\mathrm{DTR} /+}$ mice is shown in Figure $2 \mathrm{E}$. Although the spatial distribution of supporting cell nuclei appears to have undergone a moderate degree of rearrangement after hair cell loss, we observed no significant differences between the numbers of supporting cells in DT-treated Pou $43^{+/+}$mice versus Pou $43^{\text {DTR/+ }}(p=0.9126$, one-way ANOVA). In addition, a single DT injection in 6-week-old Pou $43^{\text {DTR/+ }}$ mice did not cause a 

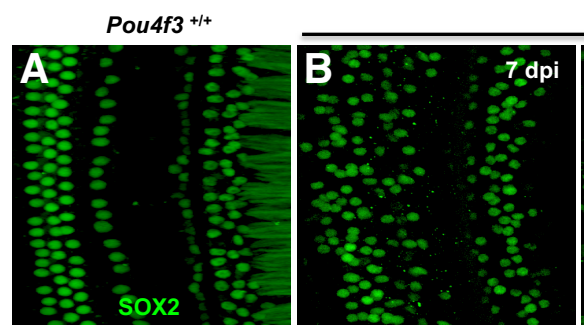

Pou4f3 DTR/+
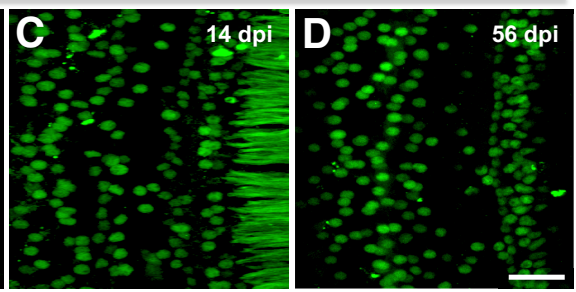

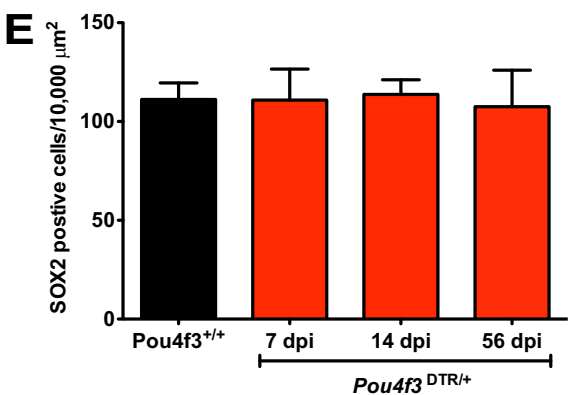

$\mathbf{J}$

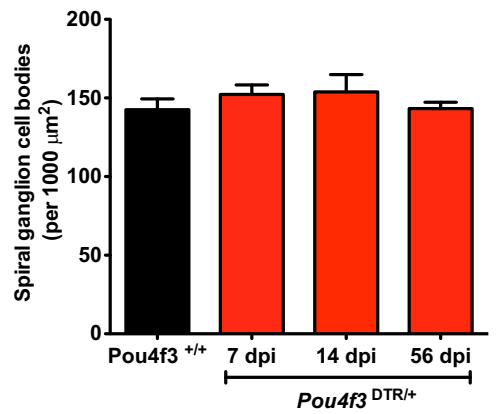

Figure 2. Cochlear supporting cells and SGNs are not affected by DT-mediated hair cell ablation. Top row, Cochlear whole mounts immunolabeled for SOX2 (green, supporting cells) from (A) Pou4f3 $3^{+/+}$and Pou $4 f^{\mathrm{BTR} /+}$ mice at $(\boldsymbol{B}) 7 \mathrm{~d},(C) 14 \mathrm{~d}$, and (D) $56 \mathrm{~d}$ after DT injection. We observed no evidence for the loss of supporting cells, despite the complete ablation of both inner and outer hair cells. Supporting cell nuclei change their shape and frequently redistribute after hair cell loss. $E$, Average number of SOX2-positive supporting cells at various times after DT injection. Bottom row, Mid-modiolar sections labeled for neurofilament and $\beta$-III tubulin (red, neurons) from $(\boldsymbol{F})$ Pou4f3 ${ }^{+/+}$and (G-I) Pou4f3 ${ }^{\text {TTR/+ }}$ mice at 7,14 , and $56 \mathrm{~d}$ following DT injection. No loss of spiral ganglion cell bodies was evident at any survival time. J, Average SGN density from the middle region of the cochlea at various survival times. Data are mean $\pm S D ; n=4-6$ per group. Scale bar, $30 \mu \mathrm{m}$.

significant loss of SGN (Fig. $2 F-J$ ). The average densities of spiral ganglion neurons in the middle cochlear turn of Pou $43^{+/+}$mice are compared in Figure 2J. No significant difference in SGN numbers was noted at any time point (Fig. $2 J ; p=0.8353$, oneway ANOVA). Finally, examination of other cochlear regions, such as spiral limbus and stria vascularis in the DT-treated Pou $4 \mathrm{f}^{\mathrm{DTR} /+}$ mice (at 3 and $56 \mathrm{dpi}$ ) showed no obvious morphological changes at any time point (data not shown). These results are consistent with those reported for Pou $4 \mathrm{f}^{\mathrm{DTR} /+}$ mice on a CBA/CaJ background (Tong et al., 2015) and suggest that a single DT injection in mice that possess the Pou $4 \mathrm{f3}^{\mathrm{DTR} /+}$ transgene results in the rapid and complete loss of hair cells without any apparent effect on other cell types in the cochlea. Moreover, administration of DT to mice that lack the huDTR transgene $\left(\right.$ Pou $4 \mathrm{f3}^{+/+}$) does not lead to hair cell loss or other obvious morphological changes.

\section{DT-induced hair cell ablation recruits macrophages to the damaged sensory epithelium}

Prior studies have demonstrated that macrophages are recruited into the cochlea after acoustic trauma (Fredelius and RaskAndersen, 1990; Hirose et al., 2005) or aminoglycoside ototoxicity (Sato et al., 2010). However, it is unclear whether this increase in macrophages was entirely attributable to hair cell death or whether other tissue injury caused by noise or ototoxic insults might also attract macrophages. Data above demonstrate that treatment of Pou $43^{\mathrm{DTR} /+}$ mice with a single injection of DT results in complete loss of hair cells, without any apparent effect on the other cells of the cochlea. As such, this mouse model can be used to study the role of hair cell death as an initiator of immune cell recruitment into the injured cochlea. Pou $4 \mathrm{f}^{\mathrm{DTR} /+}$ mice were crossed to $C X_{3} C R 1^{G F P / G F P}$ mice, in which all macrophages, monocytes, microglia, and NK cells express GFP (Jung et al.,
2000). Double heterozygotes (Pou $4 f^{\mathrm{DTR} /+}: C X_{3} C R 1^{+/ G F P}$ ) were used as experimental mice, whereas single heterozygotes $\left(\right.$ Pou $\left.43^{+/+}: C X_{3} C R 1^{+/ G F P}\right)$ served as controls. Both experimental and control mice ( $n=6$ in each group) were injected with a single dose of DT $(25 \mathrm{ng} / \mathrm{g})$ and allowed to recover for $1,3,7,14$, 28 , and $56 \mathrm{~d}$ after injection. At these points, temporal bones were harvested and processed for immunolabeling of nerve fibers and GFP. Macrophage numbers along the sensory epithelium were quantified and expressed as macrophages $/ 100 \mu \mathrm{m}$ of basilar membrane length. Very few macrophages $(0-4 / 100 \mu \mathrm{m})$ were present in sensory epithelium of uninjured (control) cochleae (Fig. $3 A$ ), and those macrophages were usually located in the osseous spiral lamina and only rarely observed below the sensory epithelium. Treatment with DT resulted in enhanced numbers of GFP-expressing macrophages in the Pou $43^{\mathrm{DTR} /+}$ mice, but not in the Pou $4 \mathrm{f}^{+/+}$mice (Fig. $3 B-D$ ). This increase in macrophages was first noted at $3 \mathrm{~d}$ after DT, the time when hair cell death is first evident (see above). Macrophages in the lesioned sensory epithelia of Pou $43^{\text {DTR/+ }}$ mice were typically located below the basilar membrane among the tympanic mesothelial cells and in the osseous spiral lamina next to the inner sulcus region (Fig. 3E). The numbers of macrophages associated with the sensory epithelium peaked at $14 \mathrm{~d}$ after DT and then declined at later survival times (Fig. $3 F$ ). Macrophage numbers in Pou $4 \mathrm{f}^{\mathrm{DTR} /+}$ mice at $3,7,14$, 28 , and $56 \mathrm{~d}$ after DT were significantly different from those in Pou $4 \mathrm{f3}^{+/+}$mice (black bars) at respective time points $(p<0.01$; $p<0.0001)$ and from $1 \mathrm{~d}$ after survival $(p<0.001$, analyzed by two-way ANOVA followed by Tukey's multiple comparisons post hoc tests). Proliferation assays using BrdU incorporation (S-phase) and phosphohistone H3 (M-phase) immunolabeling indicated that these macrophages had not undergone DNA replication within $48 \mathrm{~h}$ of hair cell ablation, suggesting that the macrophage increase was due to infiltration of circulating monocytes, 

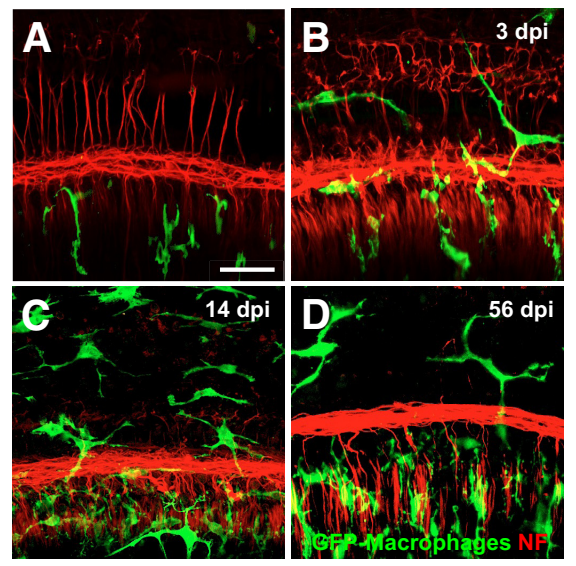

\section{$F$}
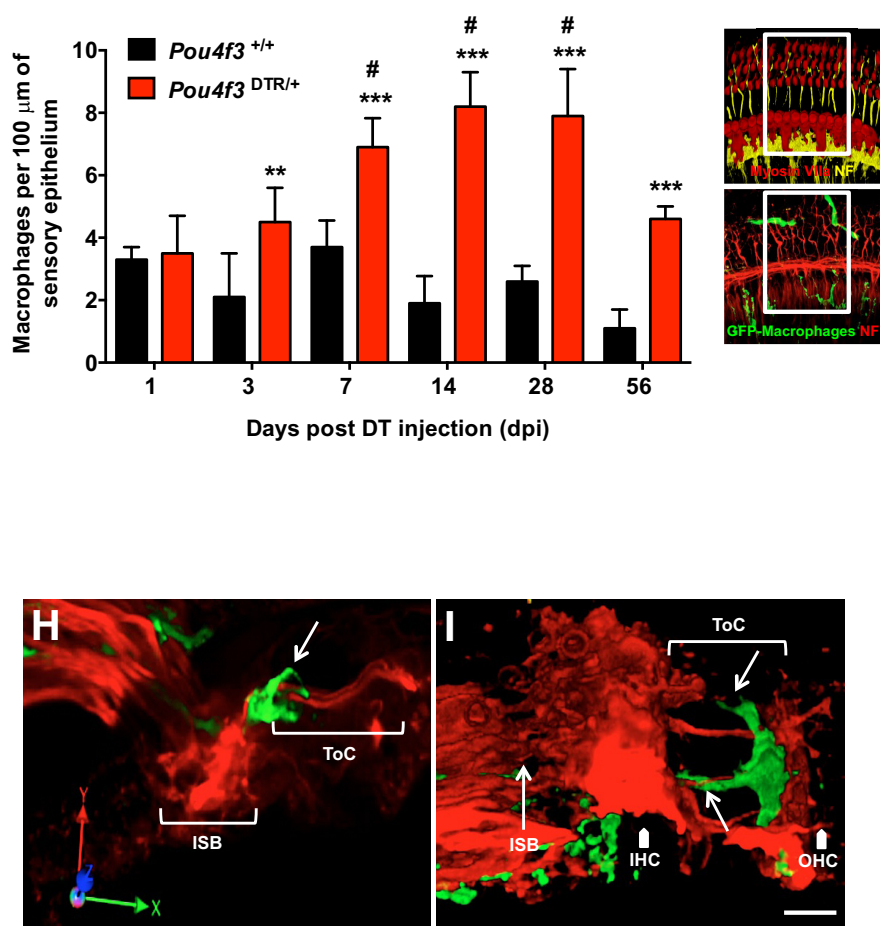

GFP-Macrophages NF Phalloidin

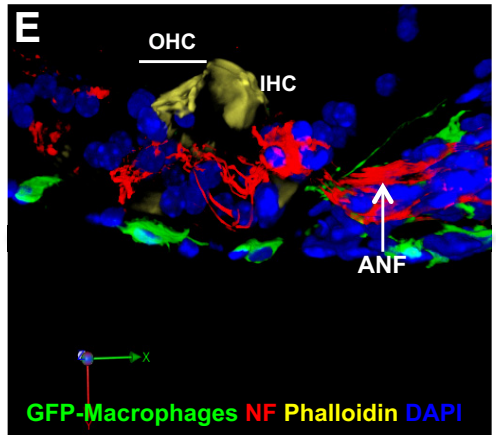

Figure 3. Loss of hair cells is sufficient to recruit macrophages toward the cochlear sensory epithelium. Pou4f3 ${ }^{+/+}$(control) and Pou4f3 ${ }^{\text {DTR/ }+}$ mice received a single DT injection, and cochleae were examined at $1,3,7,14,28$, and 56 d recovery. $\boldsymbol{A}-\boldsymbol{D}$, Cochlear whole mounts showing GFP-labeled macrophages (green) and neurons (Neurofilament and $\beta$-III tubulin, red) demonstrate increased numbers of macrophages within the sensory regions of lesioned (e.g., Pou $4 f 3^{\text {DTR/+}}$ ) mice $(\boldsymbol{B}-\boldsymbol{D})$, compared with controls $(\boldsymbol{A})$. Elevated macrophage numbers were first observed at $3 \mathrm{~d}$ after DT. $\boldsymbol{E}$, The 3D renderings of confocal image stacks of lesioned cochleae show that macrophages (green) are typically located below the basilar membrane among the tympanic mesothelial cells and in the osseous spiral lamina. $\boldsymbol{F}$, Quantification of macrophages per $100 \mu \mathrm{m}$ of sensory epithelium. Macrophage numbers near the sensory epithelium peak at $14 \mathrm{dpi}$ and diminish by $56 \mathrm{dpi}$. $\mathbf{G}$, The area in the sensory epithelium (white box) of the cochlea from which macrophages were counted. $\boldsymbol{H}, \boldsymbol{I}$, The $3 D$ renderings obtained from confocal image stacks of lesioned cochleae show that macrophages (green) are often in close contact with neurons (red) crossing the tunnel of Corti (white arrows) and extended processes toward hair cells (position shown with white arrowheads). Data are mean \pm SD; $n=6$ per group. dpi, days post injection; NF, neurofilament; IHC, inner hair cell; OHC; outer hair cell; ISB; inner spiral bundle; ToC; tunnel of Corti Statistical significance was computed

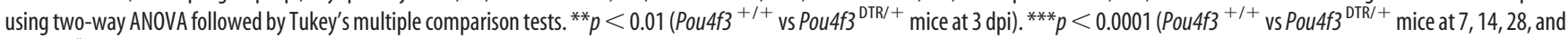
$56 \mathrm{dpi}$ ). ${ }^{\#} p<0.001$ (1 dpi vs all others). Scale bar, $30 \mu \mathrm{m}$.

rather than proliferation of resident macrophages (data not shown). Together, these results suggest that the death of hair cells, without any other apparent otic pathology, is sufficient to recruit macrophages into the inner ear.

\section{Injury-evoked changes in peripheral processes of cochlear neurons}

We qualitatively assessed the integrity of the peripheral neuronal processes terminating in the inner and outer hair cell regions, using antibodies against neurofilament and $\beta$-III tubulin (Fig. $3 A-D$, red: nerve fibers). In DT-injected Pou $43^{\mathrm{DTR} /+}$ mice, the processes within the organ of Corti appeared normal until 2 weeks after injection (Fig. 3B). GFP-expressing macrophages were often observed in close proximity with nerve fibers that contacted both inner and outer hair cells as early as $7 \mathrm{~d}$ after injection (Fig. $3 H, I$, indicated by arrows).

\section{DT-induced hair cell ablation recruits cochlear macrophages into the spiral ganglion}

Our results, which are consistent with those of Tong et al. (2015), indicate that SGNs can survive without hair cell targets for (at least) $56 \mathrm{~d}$ after DT treatment (Fig. $2 F-J$ ). Nevertheless, we found that DT-mediated hair cell loss led to increased macrophage numbers within the Rosenthal canal region of the cochlea and associated with the SGN cell bodies. Enhanced numbers of macrophages in the spiral ganglion were observed, beginning at $7 \mathrm{~d}$ after DT. However, unlike the pattern observed in the sensory region of the cochlea, the number of macrophages within the spiral ganglion remained elevated at long recovery times (Fig. $4 A-E$ ). Quantification of macrophages in spiral ganglia at $7,14,28$, and 56 after DT revealed significant differences between Pou $4 \mathrm{f}^{\mathrm{DTR} /+}$ and Pou $4 \mathrm{f3}^{+/+}$mice (Fig. $4 E ; p<0.001$, by two-way ANOVA followed by Bonferroni's multiple comparisons post hoc tests).

\section{$\mathrm{CX}_{3} \mathrm{CL} 1-\mathrm{CX}_{3} \mathrm{CR} 1$ signaling modulates macrophage recruitment to the injured cochlea}

Although the death of hair cells is apparently sufficient to recruit macrophages into the injured cochlea, the chemical signals that mediate this signal are not known. Studies of injury to other tissue types indicate that fractalkine $\left(\mathrm{CX}_{3} \mathrm{CL} 1\right)$ can stimulate macrophage chemotaxis (Truman et al., 2008; Fuhrmann et al., 2010), but the cochlear expression of $\mathrm{CX}_{3} \mathrm{CL} 1$ has not been characterized. Using antibodies directed against the chemotactic domain of fractalkine, we observed immunoreactivity for $\mathrm{CX}_{3} \mathrm{CL} 1$ on mature spiral ganglion cell bodies (Fig. $5 B-D$ ). This labeling was specific to $\mathrm{SGN}$ soma, and we did not observe any immunoreactivity in the surrounding Schwann cells and satellite cells (Fig. 5E-G). Within the cochlear sensory epithelium, we also observed immunolabeling for $\mathrm{CX}_{3} \mathrm{CL} 1$ 

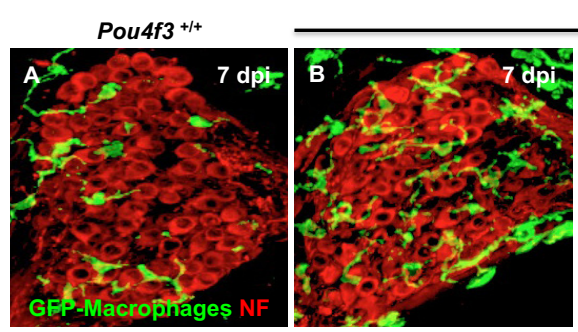

Pou4f3 DTR/+

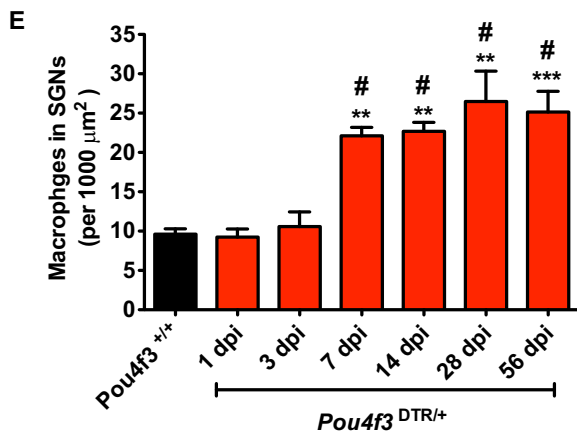

Figure 4. Loss of hair cells leads to increased numbers of macrophages in the spiral ganglion. Pou4f3 ${ }^{+/+}$and Pou4f3 ${ }^{\text {DTR/+ }}$ mice were injected with DT, and cochleae were examined at $1,3,7$, 14,28 , and $56 \mathrm{~d}$ recovery. A, Mid-modiolar frozen section from a DT-treated Pou4f3 ${ }^{+/+}$(control) mouse, showing GFP-expressing macrophages (green) and neurons (Neurofilament/TUJ-1, red). $B-D$, Comparable images taken from mid-modiolar sections of DT-treated Pou4f3 ${ }^{\text {TTR/+ }}$ mice at various recovery times. E, Quantification of macrophage numbers per $1000 \mu \mathrm{m}^{2}$ of spiral ganglia (middle region of the cochlea) of control and Pou4f3 ${ }^{\mathrm{DTR} /+}$ mice. Increased numbers of macrophages were observed in mice that had DT-induced hair cell lesions. Notably, macrophage numbers remained elevated as late as $56 \mathrm{~d}$ after DT. Data are mean $\pm S D ; n=3-7$ per group. ${ }^{* *} p<0.01,1$ dpi vs 7,14 , and $28 \mathrm{dpi}$ (two-way ANOVA followed by Bonferroni's multiple comparisons post hoc

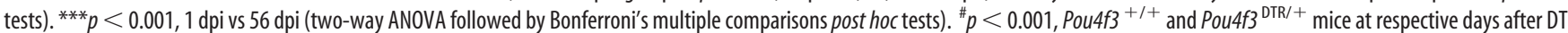
injection (two-way ANOVA followed by Bonferroni's multiple comparisons post hoc tests). dpi, days post DT injection. Scale bar, $30 \mu \mathrm{m}$.

on Deiter's, pillar cells, and on inner hair cells, but we did not observe $\mathrm{CX}_{3} \mathrm{CL} 1$ immunoreactivity on outer hair cells (Fig. 5A).

We next used a genetic approach to characterize the role of fractalkine signaling after hair cell injury. Mice were crossed to produce four distinct genotypes: either Pou $4 \mathrm{f}^{+/+}$or Pou $4 \mathrm{f}^{\mathrm{DTR} /+}$ as well as either $\mathrm{CX}_{3} \mathrm{CR} 1^{\mathrm{GFP} /+}$ or $C X_{3} C R 1^{\mathrm{GFP} / \mathrm{GFP}}$. Mice that were $\mathrm{CX}_{3} C R 1^{G F P /+}$ possessed a single copy of $C X_{3} C R 1$ and retained normal fractalkine signaling, whereas mice that were $C X_{3} C R 1^{G F P / G F P}$ lacked the ability to respond to fractalkine. All mice received DT, and cochleae were fixed and processed after $14 \mathrm{~d}$ survival. Consistent with previous results, there was an increase ( $\sim 4$-fold) in the numbers of macrophages associated with the cochlear sensory epithelia in Pou4f3 $3^{\mathrm{DTR} /{ }^{+}}$: $\mathrm{CX}_{3} C R 1^{\mathrm{GFP} /+}$ mice (Fig. $\left.6 A^{\prime}\right)$. However, fewer macrophages $(\sim 60 \%)$ were observed in the DT-lesioned mice that lacked $\mathrm{CX}_{3} \mathrm{CR} 1\left(\mathrm{CX}_{3} \mathrm{CR} 1^{\mathrm{GFP} / \mathrm{GFP}}\right.$; Fig. $\left.6 B^{\prime}\right)$. Deletion of $\mathrm{CX}_{3} \mathrm{CR} 1 \quad\left(C X_{3}\right.$ $C R 1^{G F P / G F P}$ ) did not affect the numbers of resident macrophages in (undamaged) cochleae of Pou4f3 ${ }^{+/+}$mice (Fig. 6B), which were similar to those in undamaged $\mathrm{CX}_{3} \mathrm{CR}^{+/-}$mice (Fig. 6A). Complete quantitative data are shown in Figure 6 C.

Disruption of fractalkine signaling also reduced macrophage numbers in the spiral ganglia of Pou $43^{\text {DTR/+ }}$ mice (Fig. $6 D-G$ ). Cochlear mid-modiolar sections (obtained from specimens that were fixed at $56 \mathrm{~d}$ after DT) showed a reduction in the number of macrophages in the spiral ganglia of $\mathrm{CX}_{3} C R 1^{\mathrm{GFP} / \mathrm{GFP}}$ mice (Fig. 6E') versus $C X_{3} C R 1^{\mathrm{GFP} /+}$ mice (Fig. $6 D^{\prime}$ ). Quantification of macrophages revealed a significant reduction in macrophages in $C X_{3} C R 1^{\mathrm{GFP} / \mathrm{GFP}}$ mice versus $C X_{3} C R 1^{\mathrm{GFP} /+}$ in both the mid- and basal cochlear turns $(p<0.0001$, Fig. $6 F$ ). Notably, deletion of $\mathrm{CX}_{3} \mathrm{CR} 1$ did not affect the macrophage
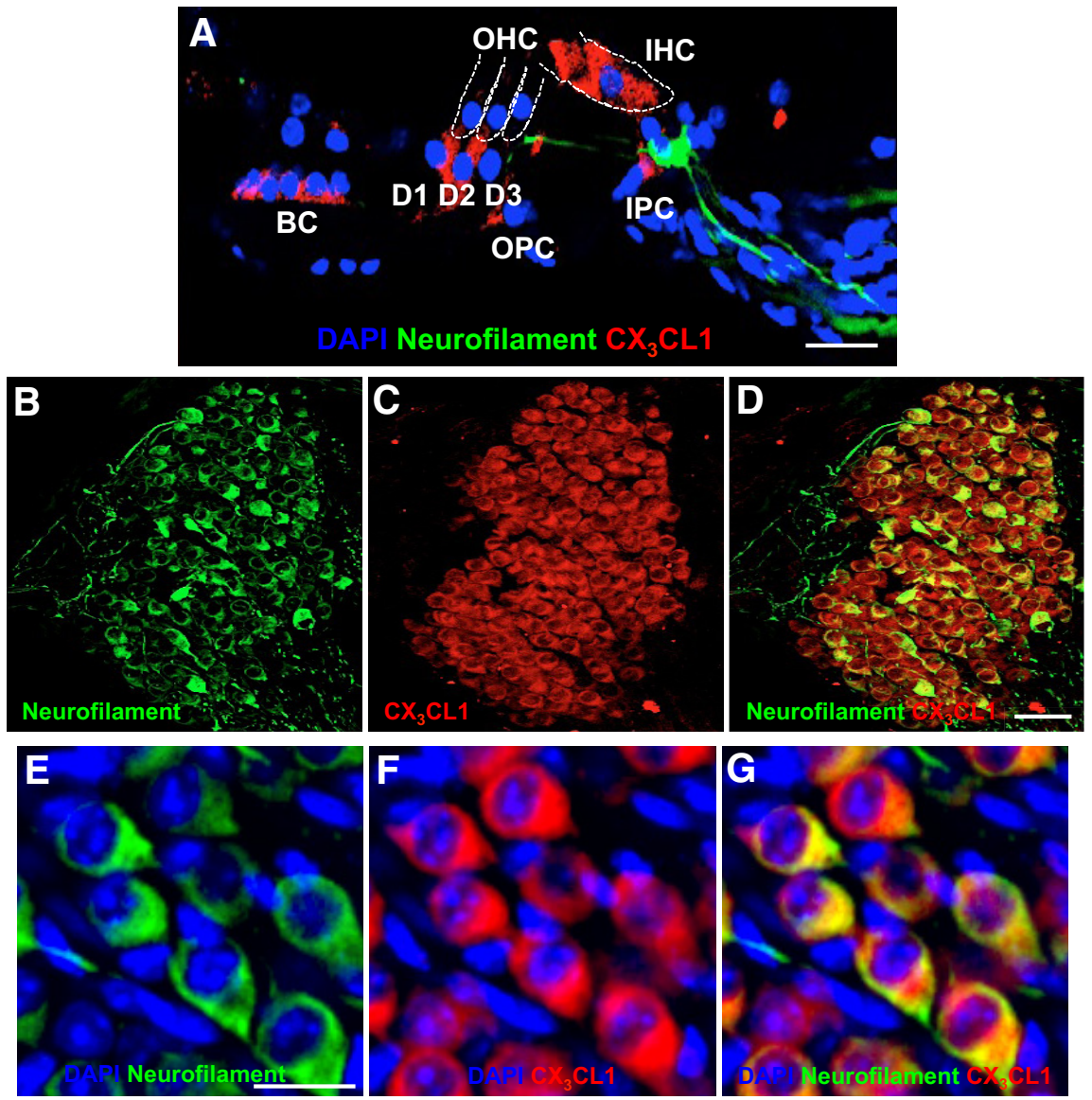

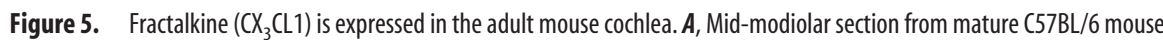
immunolabeled for fractalkine (red, antibody against the chemotactic domain of $\mathrm{CX}_{3} \mathrm{CL} 1$ ) and neurons ( $g$ reen) showing expression of $\mathrm{CX}_{3} \mathrm{CL} 1$ in certain cell types within the sensory epithelium. $\boldsymbol{B}-\boldsymbol{D}$, Mid-modiolar section, showing the spiral ganglion and labeled for fractalkine (red) and neurons (green). Immunoreactivity for $\mathrm{CX}_{3} \mathrm{CL} 1$ was observed on SGNs. E-G, Higher-magnification image reveals that $\mathrm{CX}_{3} \mathrm{CL} 1$ immunoreactivity was confined to $S G N$ somata, and was not present in surrounding Schwann and satellite cells. $\mathrm{OHC}$, Outer hair cell; $\mathrm{IHC}$, inner hair cell; $\mathrm{D} 1-3$, Dieter cell; $\mathrm{OPC}$, outer pillar cell; $\mathrm{IPC}$, inner pillar cell; $\mathrm{BC}$, Boettcher cells. Scale bars: $A, 55 \mu \mathrm{m} ; \boldsymbol{B}-\boldsymbol{D}, 20 \mu \mathrm{m} ; \boldsymbol{E}, \boldsymbol{F}, \mathbf{G}, 15 \mu \mathrm{m}$. numbers in Pou4f3 $3^{+/+}$mice (Fig. $6 E$ ), which were similar to those in Pou $43^{+/+}: C X_{3} C R 1^{\mathrm{GFP} /+}$ mice (Fig. $6 D$ ). Finally, genetic deletion of $\mathrm{CX}_{3} \mathrm{CR} 1$ appeared to reduce cochlear macrophage numbers in the spiral ganglia at all time points after DT-induced hair cell lesion (Fig. 6G). 

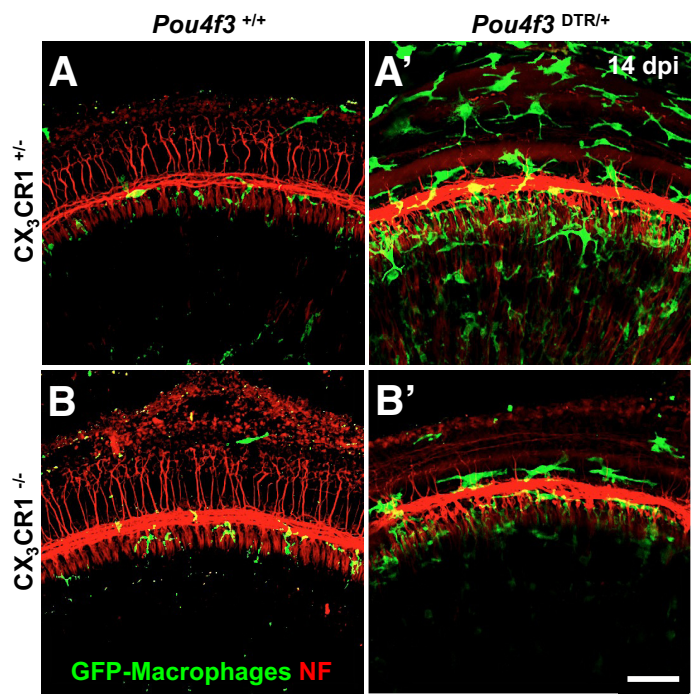

\section{$\mathbf{F}$}
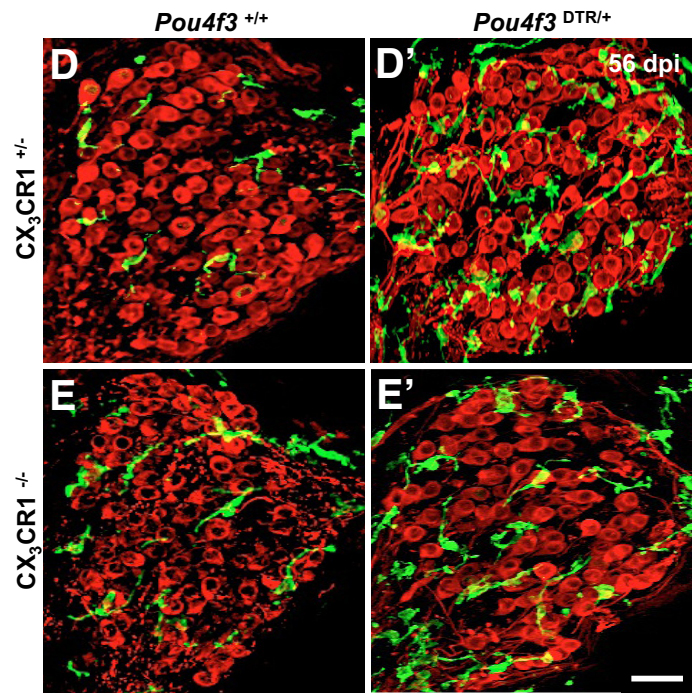

C
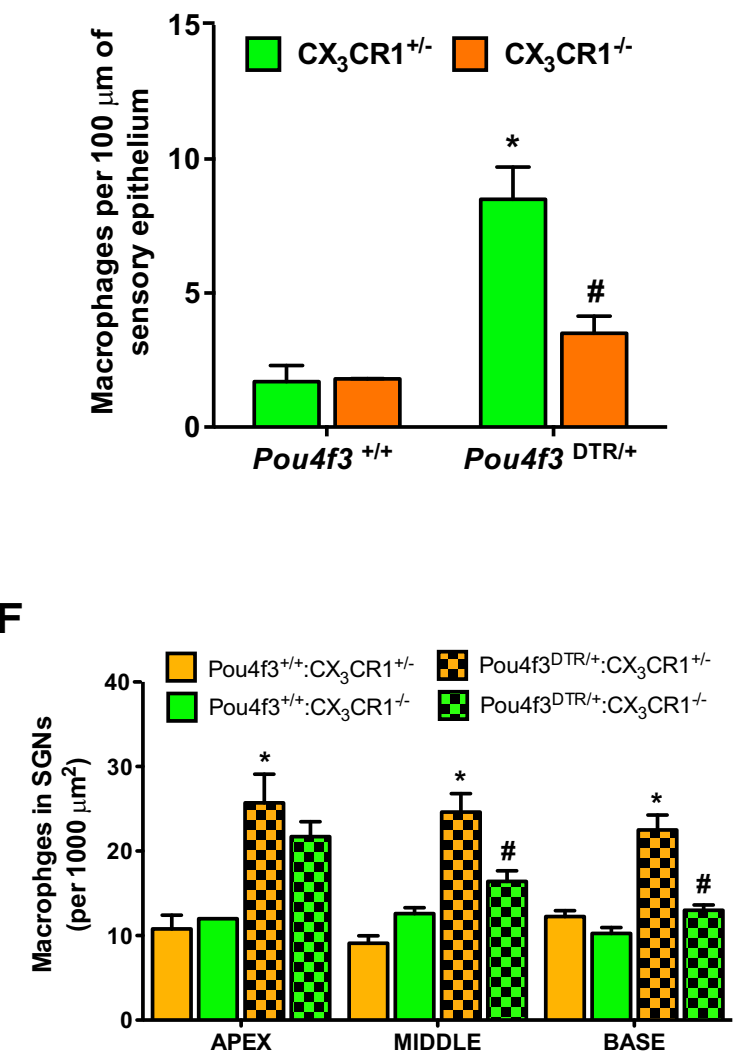

G

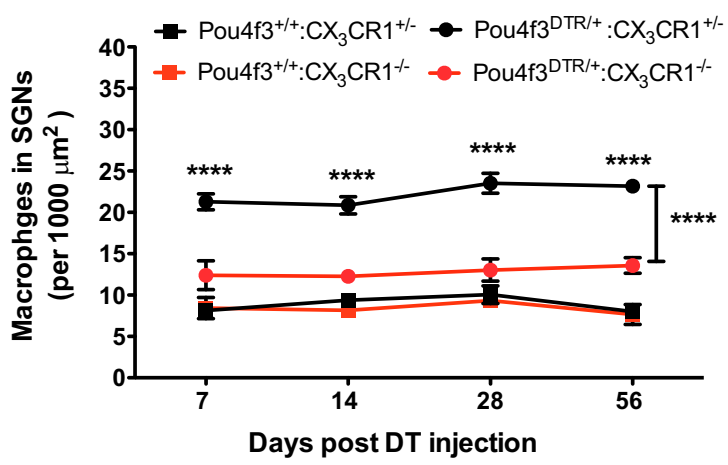

Figure 6. Genetic deletion of $C X_{3} C R 1$ led to a reduction in macrophages near the sensory epithelium after hair cell ablation. The effects of $C X_{3} C R 1$ on macrophage recruitment were assessed using

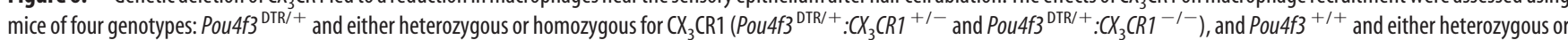
homozygous for $C X_{3} C R 1$ (Pou4f3 ${ }^{+1+}: C X_{3} C R 1^{+/-}$and Pou4f3 $\left.{ }^{+/+}: C X_{3} C R 1^{-1-}\right)$. Cochlear whole mounts and mid-modiolar sections were processed to image macrophages (CX3CR1 ${ }^{+/ G F P}$, green) and neurons (neurofilament, red). We observed a significant reduction in the numbers of macrophages near the sensory region of the cochlea $\left(\boldsymbol{B}^{\prime}\right)$ and in the spiral ganglion $\left(\boldsymbol{E}^{\prime}\right)$ in $C X_{3} C R 1^{-I-}$ mice, compared with $C X_{3}\left(R 1^{+/-}\right.$mice $\left(\boldsymbol{A}^{\prime}, \boldsymbol{D}^{\prime}\right)$ at both $14 \mathrm{~d}$ (top) and $56 \mathrm{~d}$ (bottom) after DT injection. $C, F, G$, Quantitative data on macrophages in sensory epithelium at $14 \mathrm{dpi}(\boldsymbol{C})$ and in the spiral ganglia at $56 \mathrm{dpi}(\boldsymbol{F})$. Quantification of macrophages within the spiral ganglia in the middle region of the cochlea at all time points after DT-induced hair cell lesion (G). Data are mean \pm SD; $n=3-7$ for 7 dpi per group; $n=6-7$ for 14 dpi per group; $n=3-5$ for 28 dpi per group; and $n=9-11$ for 56 dpi per group. dpi, days post DT injection; NF, Neurofilament. Statistical significance was computed

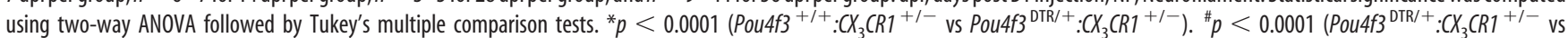
Pou4f3 ${ }^{\mathrm{DTR} /+}: C \mathrm{C}_{3}\left(R 1^{-/-}\right) \cdot p<0.05$ (Pou4f3 $^{+/+}: C X_{3} C R 1^{-/-}$vs Pou4f3 ${ }^{\mathrm{DTR} /+}: C \mathrm{CX}_{3} \mathrm{CR} 1^{-/-}$in $C$, for middle region of the cochlea in $G$, and at $56 \mathrm{~d}$ post DT in $F$. Scale bar, $30 \mu \mathrm{m}$.

\section{Deletion of $\mathrm{CX}_{3} \mathrm{CR} 1$ leads to diminished survival of SGNs}

following hair cell death

Our results, consistent with those of a previous study, indicate that DT-induced hair cell lesions in mature Pou $43^{\mathrm{DTR} /+}$ mice do not cause a significant loss of SGNs (Fig. $2 F-J$ ) (see also Tong et al., 2015). To determine whether fractalkine signaling plays a role in neuronal survival, we compared the numbers of spiral gan- glion cells in the lesioned cochleae of Pou4f3 ${ }^{\mathrm{DTR} /+}: C X_{3} C R 1^{\mathrm{GFP} / \mathrm{GFP}}$ mice (i.e., fractalkine signaling disrupted) with those in Pou $43^{\mathrm{DTR} /+}: C X_{3} C R 1^{\mathrm{GFP} /+}$ mice (i.e., fractalkine signaling intact) at $56 \mathrm{~d}$ after DT. We found that genetic deletion of the fractalkine receptor resulted in reduced numbers of SGNs in all regions of the cochlea (Fig. 7). Cochlear mid-modiolar sections that were immunolabeled for neurofilament and $\beta$-III-tubulin 

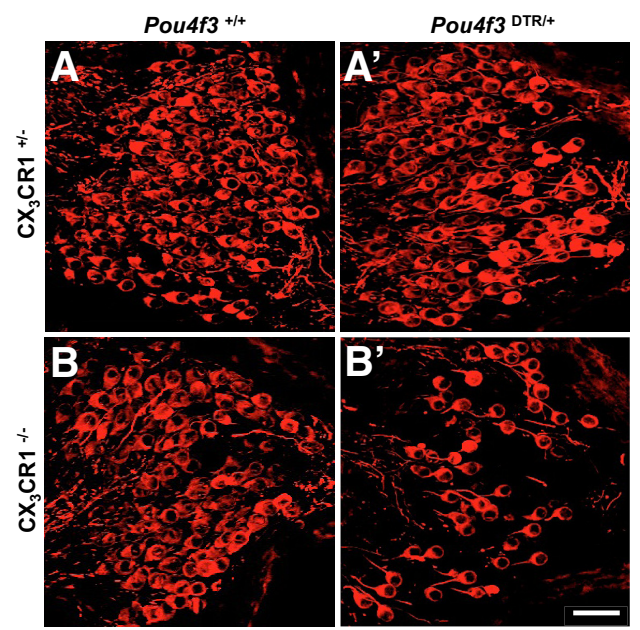

C

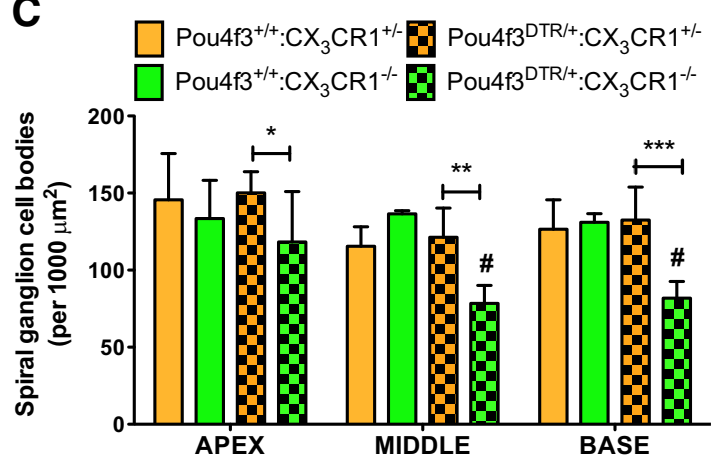

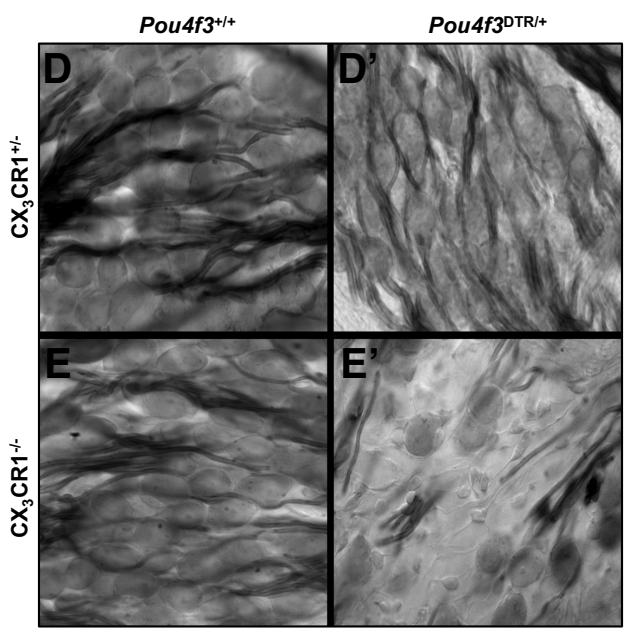

F

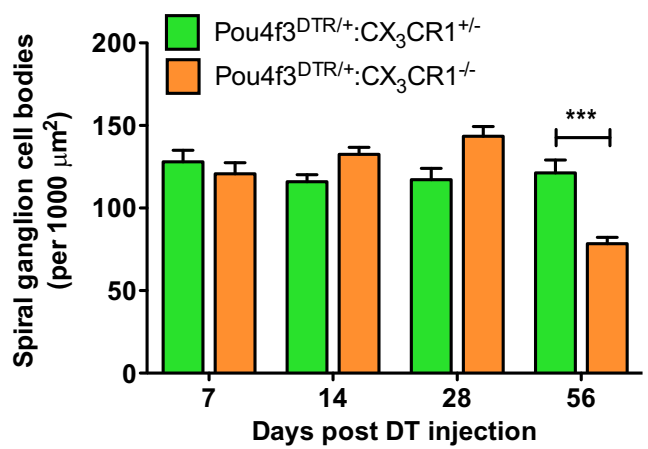

Figure 7. Genetic deletion of $C X_{3} C R 1$ results in significant loss of $S G N s$ after hair cell ablation. Cochlear mid-modiolar sections labeled for neurofilament (neurons, red) revealed significant loss of spiral ganglion cell bodies in the $C X_{3} C R 1^{-1-}$ mice $\left(\boldsymbol{B}^{\prime}\right)$, compared with $C X_{3} C R 1^{+/-}\left(\boldsymbol{A}^{\prime}\right)$ mice, at $56 \mathrm{~d}$ after DT-induced hair cell lesion. We observed no evidence for $S G N$ loss in Pou4f3 ${ }^{+/+}$mice that were either $C X_{3} C R 1^{-1-}(\boldsymbol{B}) \operatorname{or} C X_{3} C R 1^{+/-}(\boldsymbol{A}) . \boldsymbol{C}$, Quantitative data on $S G N$ density (per $\left.1000 \mu \mathrm{m}^{2}\right)$ for the four genotypes. $\boldsymbol{D}, \boldsymbol{E}$, Plastic sections from the basal cochlear turn of Pou4f3 ${ }^{+/+}$mice at $56 \mathrm{~d}$ after DT injection. Both $C X_{3} C R 1^{+/-}(\boldsymbol{D})$ and $C X_{3} C R 1^{-1-}(\boldsymbol{E})$ possessed normal numbers of SGNs. $\boldsymbol{D}^{\prime}, \boldsymbol{E}^{\prime}$, Plastic sections from the basal cochlear turn of $P$ ou $4 f 3$ DTR/+ mice at $56 \mathrm{~d}$ after $D T$ injection. Spiral ganglia of $C X_{3} C R 1^{+1-}$ mice $\left(\boldsymbol{D}^{\prime}\right)$ contained normal numbers of auditory neurons after hair cell lesions, whereas the ganglia of $C X_{3} C R 1^{-I-}$ mice $\left(\boldsymbol{E}^{\prime}\right)$ showed diminished neuronal survival. $\boldsymbol{F}$, Density of SGNs (per $1000 \mu \mathrm{m}^{2}$ ) from the basal cochlear turn at all time points after DT-induced hair cell lesion. Data are mean \pm SD; $n=5-10$ per group. dpi, days post-DT injection. Statistical significance was computed using two-way ANOVA followed by Tukey's multiple comparison post hoc tests. ${ }^{*} p<0.05$. ${ }^{* *} p<0.01 .{ }^{* * *} p<0.001\left(P o u 4 f 3{ }^{\text {DTR/+ }}: X_{3} C R 1^{+/-}\right.$vs

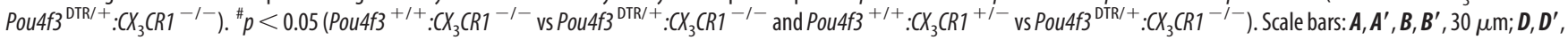
$E_{,} \boldsymbol{E}^{\prime}, 10 \mu \mathrm{m}$.

show significant loss of spiral ganglion cell bodies in the $C X_{3} C R 1^{\mathrm{GFP} / \mathrm{GFP}}$ mice (Fig. $7 B^{\prime}, C$ ), compared with $C X_{3} C R 1^{\mathrm{GFP} /+}$ mice (Fig. $7 A^{\prime}, C$ ). No reduction in SGNs was observed in Pou $43^{+/+}: C X_{3} C R 1^{\text {GFP/GFP }}$ mice, suggesting that the loss of neurons occurred only after hair cell death. Examination of spiral ganglion cell bodies in plastic-embedded sections confirmed these findings (Fig. $7 D^{\prime}, E^{\prime}$ ). At $56 \mathrm{~d}$ after DT, the average density of SGNs in $C X_{3} C R 1^{\mathrm{GFP} / \mathrm{GFP}}$ mice was $10.19 \pm 1.17$ per 10,000 $\mu \mathrm{m}^{2}$, which was significantly different from that observed in $C X_{3} C R 1^{\mathrm{GFP} /+}$ mice $(20.75 \pm 1.78 ; p<0.0001$, Student's $t$ test $)$. This loss of neurons was only observed at the $56 \mathrm{~d}$ recovery time point; we did not see evidence for SGN loss in $C X_{3} C R 1^{-1-}$ mice at 7, 14, and $28 \mathrm{~d}$ after DT (Fig. $7 F$ ). These results suggest that fractalkine signaling may participate in those processes that maintain the survival of SGNs at long periods after hair cell death.

\section{Discussion}

Our results confirm that the mammalian cochlea contains a resident population of macrophages and that their numbers are increased after cochlear injury. Because the Pou $4 f 3-h u D T R$ model permits the selective ablation of hair cells without damaging other cells types, our data further suggest that loss of hair cells alone is sufficient to recruit macrophages into the cochlea. Hair cell injury also resulted in enhanced macrophage numbers within the spiral ganglion, and those numbers remained elevated for 2 months or longer. Finally, genetic deletion of $\mathrm{CX}_{3} \mathrm{CR} 1$ reduced macrophage recruitment and also impaired the survival of SGNs after the loss of their hair cell targets. These findings point to a previously unreported interaction between macrophages and the afferent neurons of the cochlea.

\section{The Pou $4 \mathrm{f}^{\mathrm{DTR} /+}$ mouse model enables selective hair cell} lesion in the mature cochlea

The Pou4f3-huDTR transgenic mouse line has been characterized in several previous publications, some of which involved mice with a different genetic background than in the present study (Golub et al., 2012; Tong et al., 2015). We observed nearly identical results to those prior studies. Treatment with DT led to hair cell death, which was first noted at $3 \mathrm{~d}$ after DT injection, and the loss of nearly all inner hair cells and outer hair cells was apparent after $7 \mathrm{~d}$. We also observed no DT-induced hair cell death in mice that lacked the Pouff3-huDTR transgene. Functional analysis (ABRs and DPOAEs) of the DT-treated Pou4f3-huDTR mice revealed profound and irreversible hearing loss. In addition, we 
observed an acute reduction in the endocochlear potential after DT-induced hair cell lesions, which is likely attributable to disruption of the reticular lamina following hair cell death (Ahmad et al., 2003). These observations suggest that DT specifically targets hair cells in this transgenic line, without causing injury to other otic cell phenotypes.

\section{Loss of cochlear hair cells is sufficient for macrophage recruitment}

Macrophages are recruited into the cochlea after acoustic trauma (Fredelius and Rask-Andersen, 1990; Hirose et al., 2005) and aminoglycoside ototoxicity (Sato et al., 2010). However, because both noise and ototoxins can injure multiple cell types within the ear, it was unclear whether the injury-evoked increase in macrophages was caused by hair cell death or by damage to nonsensory tissues of the cochlea. In the present study, Pou $43^{\mathrm{DTR} /+}$ mice were crossed to $C X_{3} C R 1^{G F P / G F P}$ mice, yielding offspring that expressed GFP in all macrophages and also displayed specific hair cell death in response to DT treatment. We observed increased macrophage numbers after DT-induced lesions, particularly near and below the injured sensory epithelium. In contrast, DTinduced hair cell death did not cause any significant changes in the numbers of macrophages in the cochlear lateral wall, spiral ligament, or spiral limbus. This outcome is quite different from that observed after cochlear injury caused by noise or aminoglycoside antibiotics, where enhanced numbers of macrophages are observed in many nonsensory regions of the cochlea (Hirose et al., 2005; Sato et al., 2010). The present results suggest that hair cell death without any accompanying cochlear pathology is sufficient to attract macrophages into the organ of Corti.

\section{Function of macrophages in maintaining the cochlear sensory epithelium}

Macrophages are known to act as "professional" phagocytes at sites of tissue injury, removing the corpses of dead cells. Similar function has been observed within the vestibular organs of DTtreated Pou4f3-huDTR mice (Kaur et al., 2015). However, we did not observe macrophages engulfing apoptotic hair cell debris in the organ of Corti of DT-treated Pou4f3-huDTR mice. Macrophage-mediated phagocytosis is likely to occur quickly, so we cannot exclude the possibility that we simply missed such events in our samples. We also noted an increase in macrophage volume and expression of CD68 (component of lysosomeassociated membrane proteins, phagocytic marker) on cochlear macrophages after DT-induced hair cell death, which is suggestive of phagocytic activity (data not shown). Nevertheless, the relative paucity of observed phagocytosis by macrophages, combined with the recent demonstration that dying outer hair cells are engulfed by surrounding Deiter's cells (Anttonen et al., 2014), suggests that macrophages may play a relatively minor role in the removal of debris from the injured cochlea. In addition to clearing debris, macrophages and their secretory products can also promote cellular and tissue repair (Stefater et al., 2011). The possible involvement of macrophages in cochlear epithelial repair will require further experiments.

\section{Fractalkine signaling influences macrophage numbers after hair cell death}

Resident macrophages often remove dying cells from injured tissues, so as to minimize subsequent inflammation (e.g., Gregory and Devitt, 2004). Apoptotic cells recruit macrophages via the release of a number of different chemoattractants. Among these, fractalkine $\left(\mathrm{CX}_{3} \mathrm{CL} 1\right)$ has been shown to promote activation and recruitment of monocytes and microglia (Cardona et al., 2006; Auffray et al., 2007; Ransohoff et al., 2007; Fuhrmann et al., 2010). We observed $\mathrm{CX}_{3}$ CL1 immunoreactivity on inner hair cells, cochlear supporting cells, and spiral ganglion cell bodies. We also found that genetic deletion of $\mathrm{CX}_{3} \mathrm{CR} 1$ (the receptor for $\mathrm{CX}_{3} \mathrm{CL} 1$, expressed by macrophages and monocytes) resulted in diminished macrophage accumulation following cochlear injury. These results suggest that fractalkine signaling plays an important role in the regulation of macrophages after injury to cochlear hair cells. However, the precise relationship between fractalkine signaling and macrophage recruitment may be complex. A prior study has shown that genetic deletion of $\mathrm{CX}_{3} \mathrm{CR} 1$ caused increased macrophage recruitment into certain regions of the cochlea after kanamycin ototoxicity (Sato et al., 2010). This enhancement of macrophage numbers was particularly evident in the cochlear lateral wall, a structure that is damaged by aminoglycosides (Schmitz et al., 2014), but not by the DT treatment used in the present study. Finally, genetic deletion of fractalkine signaling does not affect macrophage recruitment or behavior in the vestibular organs after similar hair cell lesions (Kaur et al., 2015).

\section{Interaction between macrophages and SGNs}

Our finding that SGNs survive for (at least) 2 months after DTmediated hair cell loss is consistent with a previous study that used the same mouse model (Tong et al., 2015) and supports the idea that mature SGNs do not require ongoing trophic support from cochlear hair cells. Slow secondary degeneration of SGNs can occur after hair cell injury caused by acoustic trauma and ototoxicity (e.g., Oesterle and Campbell, 2009). Despite the lack of SGN degeneration, we still observed a significant increase in macrophages within the spiral ganglion after DT injection. Moreover, the macrophage population within the ganglion remained elevated for (at least) $56 \mathrm{~d}$ after DT. Such observations suggest a long-term interaction between macrophages and SGNs after cochlear injury.

Previous studies have shown that cochlear supporting cells are critical for promoting long-term survival of SGNs in the absence of hair cells (Stankovic et al., 2004; Sugawara et al., 2005; Zilberstein et al., 2012). Our findings indicate that macrophages and/or fractalkine signaling also play an important role in maintaining viable SGNs after the loss of their target hair cells. The complimentary expression of $\mathrm{CX}_{3} \mathrm{CL} 1$ on SGNs and $\mathrm{CX}_{3} \mathrm{CR} 1$ on macrophages suggests that cochlear afferents may communicate with macrophages via fractalkine release. The downstream effects of fractalkine signaling are complex and can lead to several distinct outcomes. Once synthesized by expressing cells, fractalkine is trafficked to the cell membrane, where it is anchored and extends from the extracellular surface (Pan et al., 1997; Wong et al., 2014). Activation of ADAM-family metalloproteases results in cleavage of the fractalkine protein, thereby releasing the soluble fragment into the surrounding fluid. It is possible that hair cell injury and/or the accompanying loss of afferent activity may trigger the activation of metalloproteases, leading to the release of soluble fractalkine and recruitment of macrophages. Such a mechanism would account for the reduction in SGN macrophages that was observed in the lesioned cochleae of $C X_{3} C R 1^{\text {GFP/GFP }}$ mice. However, direct interaction between membrane-bound $\mathrm{CX}_{3} \mathrm{CL} 1$ and $\mathrm{CX}_{3} \mathrm{CR} 1$ can also mediate cell adhesion, so it is possible that binding of fractalkine (on SGNs) to receptors (on macrophages) serves to stabilize the presence of macrophages in the vicinity of the ganglion cell bodies. Elimination of $\mathrm{CX}_{3} \mathrm{CR} 1$ would disrupt this process and result in fewer macrophages within the SGN. 
Either mechanism is consistent with the present data, and these mechanisms are not mutually exclusive.

Our data further indicate that deletion of $\mathrm{CX}_{3} \mathrm{CR} 1$ leads to reduced SGN numbers after hair cell injury. How might macrophages and/or fractalkine signaling affect the survival of cochlear afferents? Studies of the CNS have revealed that signaling via fractalkine can regulate the activation status of microglia and affect the production and release of several cytokines (Biber et al., 2007). If similar signaling processes were present in cochlear macrophages, then fractalkine signaling may regulate certain neuroprotective or neurotoxic properties of those macrophages after injury. It is possible, for example, that recruited macrophages produce a neurotrophic factor that enhances SGN survival after hair cell loss. This notion is supported by prior studies, which suggest that macrophages and microglia can promote neuronal survival via the production and release of neurotrophic factors, such as BDNF and IGF (Lauro et al., 2010; Parkhurst et al., 2013). In this case, the reduction in SGN survival observed in $\mathrm{CX}_{3} \mathrm{CR} 1$-knock-out mice might be attributed to a deficit in the recruitment of neurotrophin-expressing macrophages in those animals. However, additional studies of the CNS have shown that deletion of $\mathrm{CX}_{3} \mathrm{CR} 1$ can also lead to a dysregulation of microglial behavior, resulting in neurotoxicity (Cardona et al., 2006; Bhasker et al., 2010). Such pathology has been attributed to enhanced microglial expression of cytotoxic cytokines, such as interleukin-1 $\beta$. A similar mechanism in cochlear macrophages might explain the loss of SGNs reported here. Even though genetic deletion of $\mathrm{CX}_{3} \mathrm{CR} 1$ resulted in fewer macrophages within the SGN, it is possible that the remaining macrophages were releasing cytotoxic factors that were inducing the death of nearby ganglion cells. Additional experimentation will be necessary to resolve these issues.

\section{References}

Ahmad M, Bohne BA, Harding GW (2003) An in vivo tracer study of noiseinduced damage to the reticular lamina. Hear Res 175:82-100. CrossRef Medline

Anttonen T, Belevich I, Kirjavainen A, Laos M, Brakebusch C, Jokitalo E, Pirvola U (2014) How to bury the dead: elimination of apoptotic hair cells from the hearing organ of the mouse. J Assoc Res Otolaryngol 15: 975-992. CrossRef Medline

Auffray C, Fogg D, Garfa M, Elain G, Join-Lambert O, Kayal S, Sarnacki S, Cumano A, Lauvau G, Geissmann F (2007) Monitoring of blood vessels and tissues by a population of monocytes with patrolling behavior. Science 317:666-670. CrossRef Medline

Bazan JF, Bacon KB, Hardiman G, Wang W, Soo K, Rossi D, Greaves DR, Zlotnik A, Schall TJ (1997) A new class of membrane-bound chemokine with a CX3C motif. Nature 385:640-644. CrossRef Medline

Bhaskar K, Konerth M, Kokiko-Cochran ON, Cardona A, Ransohoff RM, Lamb BT (2010) Regulation of tau pathology by the microglial fractalkine receptor. Neuron 68:19-31. CrossRef Medline

Biber K, Neumann H, Inoue K, Boddeke HW (2007) Neuronal 'On' and 'Off' signals control microglia. Trends Neurosci 30:596-602. CrossRef Medline

Cardona AE, Pioro EP, Sasse ME, Kostenko V, Cardona SM, Dijkstra IM, Huang D, Kidd G, Dombrowski S, Dutta R, Lee JC, Cook DN, Jung S, Lira SA, Littman DR, Ransohoff RM (2006) Control of microglial neurotoxicity by the fractalkine receptor. Nat Neurosci 9:917-924. CrossRef Medline

Fredelius L, Rask-Andersen H (1990) The role of macrophages in the disposal of degeneration products within the organ of Corti after acoustic overstimulation. Acta Otolaryngol 109:76-82. CrossRef Medline

Fuhrmann M, Bittner T, Jung CK, Burgold S, Page RM, Mitteregger G, Haass C, LaFerla FM, Kretzschmar H, Herms J (2010) Microglial Cx3cr1 knockout prevents neuron loss in a mouse model of Alzheimer's disease. Nat Neurosci 13:411-413. CrossRef Medline

Golub JS, Tong L, Ngyuen TB, Hume CR, Palmiter RD, Rubel EW, Stone JS
(2012) Hair cell replacement in adult mouse utricles after targeted ablation of hair cells with diphtheria toxin. J Neurosci 32:15093-15105. CrossRef Medline

Gregory CD, Devitt A (2004) The macrophage and the apoptotic cell: an innate immune interaction viewed simplistically? Immunology 113:1-14. CrossRef Medline

Harrison JK, Jiang Y, Chen S, Xia Y, Maciejewski D, McNamara RK, Streit WJ, Salafranca MN, Adhikari S, Thompson DA, Botti P, Bacon KB, Feng L (1998) Role for neuronally derived fractalkine in mediating interactions between neurons and CX3CR1-expressing microglia. Proc Natl Acad Sci U S A 95:10896-10901. CrossRef Medline

Hirose K, Discolo CM, Keasler JR, Ransohoff R (2005) Mononuclear phagocytes migrate into the murine cochlea after acoustic trauma. J Comp Neurol 489:180-194. CrossRef Medline

Jung S, Aliberti J, Graemmel P, Sunshine MJ, Kreutzberg GW, Sher A, Littman DR (2000) Analysis of fractalkine receptor CX(3)CR1 function by targeted deletion and green fluorescent protein reporter gene insertion. Mol Cell Biol 20:4106-4114. CrossRef Medline

Kaur T, Hirose K, Rubel EW, Warchol ME (2015) Macrophage recruitment and epithelial repair following hair cell injury in the mouse utricle. Front Cell Neurosci 9:150. CrossRef Medline

Lauro C, Cipriani R, Catalano M, Trettel F, Chece G, Brusadin V, Antonilli L, van Rooijen N, Eusebi F, Fredholm BB, Limatola C (2010) Adenosine A1 receptors and microglial cells mediate CX3CL1-induced protection of hippocampal neurons against Glu-induced death. Neuropsychopharmacology 35:1550-1559. CrossRef Medline

Lucas AD, Chadwick N, Warren BF, Jewell DP, Gordon S, Powrie F, Greaves DR (2001) The transmembrane form of the CX3CL1 chemokine fractalkine is expressed predominantly by epithelial cells in vivo. Am J Pathol 158:855-866. CrossRef Medline

Mahrt EJ, Perkel DJ, Tong L, Rubel EW, Portfors CV (2013) Engineered deafness reveals that mouse courtship vocalizations do not require auditory experience. J Neurosci 33:5573-5583. CrossRef Medline

Oesterle EC, Campbell S (2009) Supporting cell characteristics in longdeafened aged mouse ears. J Assoc Res Otolaryngol 10:525-544. CrossRef Medline

Ohlemiller KK, Lett JM, Gagnon PM (2006) Cellular correlates of agerelated endocochlear potential reduction in a mouse model. Hear Res 220:10-26. CrossRef Medline

Ohlemiller KK, Rice ME, Lett JM, Gagnon PM (2009) Absence of strial melanin coincides with age-associated marginal cell loss and endocochlear potential decline. Hear Res 249:1-14. CrossRef Medline

Pan Y, Lloyd C, Zhou H, Dolich S, Deeds J, Gonzalo JA, Vath J, Gosselin M, Ma J, Dussault B, Woolf E, Alperin G, Culpepper J, Gutierrez-Ramos JC, Gearing D (1997) Neurotactin, a membrane-anchored chemokine upregulated in brain inflammation. Nature 387:611-617. CrossRef Medline

Paolicelli RC, Bolasco G, Pagani F, Maggi L, Scianni M, Panzanelli P, Giustetto M, Ferreira TA, Guiducci E, Dumas L, Ragozzino D, Gross CT (2011) Synaptic pruning by microglia is necessary for normal brain development. Science 333:1456-1458. CrossRef Medline

Parkhurst CN, Yang G, Ninan I, Savas JN, Yates JR 3rd, Lafaille JJ, Hempstead BL, Littman DR, Gan WB (2013) Microglia promote learningdependent synapse formation through brain-derived neurotrophic factor. Cell 155:1596-1609. CrossRef Medline

Ransohoff RM, Liu L, Cardona AE (2007) Chemokines and chemokine receptors: multipurpose players in neuroinflammation. Int Rev Neurobiol 82:187-204. CrossRef Medline

Sato E, Shick HE, Ransohoff RM, Hirose K (2010) Expression of fractalkine receptor CX3CR1 on cochlear macrophages influences survival of hair cells following ototoxic injury. J Assoc Res Otolaryngol 11:223-234. CrossRef Medline

Schmitz HM, Johnson SB, Santi PA (2014) Kanamycin-furosemide ototoxicity in the mouse cochlea: a 3-dimensional analysis. Otolaryngol Head Neck Surg 150:666-672. CrossRef Medline

Stankovic K, Rio C, Xia A, Sugawara M, Adams JC, Liberman MC, Corfas G (2004) Survival of adult spiral ganglion neurons requires erbB receptor signaling in the inner ear. J Neurosci 24:8651-8661. CrossRef Medline

Stefater JA 3rd, Ren S, Lang RA, Duffield JS (2011) Metchnikoff's policemen: macrophages in development, homeostasis and regeneration. Trends Mol Med 17:743-752. CrossRef Medline

Sugawara M, Corfas G, Liberman MC (2005) Influence of supporting cells 
on neuronal degeneration after hair cell loss. J Assoc Res Otolaryngol 6:136-147. CrossRef Medline

Tong L, Hume C, Palmiter R, Rubel EW (2011) Ablation of mouse cochlea hair cells by activating the human diphtheria toxin receptor (DTR) gene targeted to the pou 433 locus. Proc Assoc Res Otolaryngol Abstract 836.

Tong L, Strong MK, Kaur T, Juiz JM, Oesterle EC, Hume C, Warchol ME, Palmiter RD, Rubel EW (2015) Selective deletion of cochlear hair cells causes rapid age-dependent changes in spiral ganglion and cochlear nucleus neurons. J Neurosci 35:7878-7891. CrossRef Medline

Truman LA, Ford CA, Pasikowska M, Pound JD, Wilkinson SJ, Dumitriu IE, Melville L, Melrose LA, Ogden CA, Nibbs R, Graham G, Combadiere C, Gregory CD (2008) CX3CL1/fractalkine is released from apoptotic lym- phocytes to stimulate macrophage chemotaxis. Blood 112:5026-5036. CrossRef Medline

Warchol ME, Schwendener RA, Hirose K (2012) Depletion of resident macrophages does not alter sensory regeneration in the avian cochlea. PLoS One 7:e51574. CrossRef Medline

Wong HS, Jaumouillé V, Heit B, Doodnauth SA, Patel S, Huang YW, Grinstein S, Robinson LA (2014) Cytoskeletal confinement of CX3CL1 limits its susceptibility to proteolytic cleavage by ADAM10. Mol Biol Cell 25:3884-3899. CrossRef Medline

Zilberstein Y, Liberman MC, Corfas G (2012) Inner hair cells are not required for survival of spiral ganglion neurons in the adult cochlea. J Neurosci 32:405-410. CrossRef Medline 